Contractual Savings

Institutions and Banks' Stability and Efficiency

Gregorio Impavido

Alberto R. Musalem

Thierry Tressel
This paper argues that contractual savings lassets of pension funds and life insurance companies) contribute to the improvement of banks' efficiency, credit, and liquidity risk. The authors use bank level panel data across countries to assess the impact of contractual savings on bank efficiency and lending behavior. They concentrate on profitability measures and on term transformation and credit risk indicators.

The World Bank

Financial Sector Development Department

December 2001 
Policy Research Working Paper 2751

\section{Summary findings}

Impavido, Musalem, and Tressel analyze the relationship between the development of contractual savings institutions and banks' efficiency, credit, and liquidity risks. They discuss the potential mechanisms through which the development of contractual savings institutions may affect the banking sector. They show that the development of contractual savings institutions has a significant impact on bank spreads and loan maturity.
After controlling for banks' characteristics, macroeconomic factors, and more standard indicators of financial development, they show that the development of contractual savings institutions is associated with increased efficiency of the banking system and greater resilience to credit and liquidity risks.

This paper-a product of the Financial Sector Development Department-is part of a larger effort in the department to study the effects of contractual savings on financial markets. Copies of the paper are available free from the World Bank, 1818 H Street NW, Washington, DC 20433. Please contact Patricia Braxton, room MC9-704, telephone 202-473-2720, fax 202-522-7105, email address pbraxton@worldbank.org. Policy Research Working Papers are also posted on the Web at http://econ.worldbank.org. The authors may be contacted at gimpavido@worldbank.org, amusalem@worldbank.org, or tressel@delta.ens.fr. December 2001. (27 pages)

The Policy Research 11.1 . Paper Series disseminates the findings of work in progress to encourage the exchange of ideas about development issues. An objective of the series is to get the findings out quickly, even if the presentations are less than fully polished. The papers carry the names of the authors and should be cited accordingly. The findings, interpretations, and conclusions expressed in this paper are entirely those of the authors. They do not necessarily represent the view of the World Bank, its Executive Directors, or the countries they represent. 


\title{
Contractual Savings Institutions and Banks' Stability and Efficiency
}

\author{
Gregorio Impavido, Alberto R. Musalem, and Thierry Tressel ${ }^{\dagger}$
}

\author{
The World Bank
}

JEL Classification Code: G21, G22, G23.

Keywords: Contractual savings, Banking sector, Risk management.

\footnotetext{
${ }^{\dagger}$ Gregorio Impavido (gimpavido@worldbank.org) and Alberto Roque Musalem, (amusalem@worldbank.org) are Financial Economist and Advisor, respectively, in the Financial Sector Development Department of the World Bank. Thierry Tressel (tressel@delta.ens. fr) is research fellow at DELTA (Paris, France) and consultant at the OECD.
} 



\section{INTRODUCTION}

The emerging economies' crisis stress repeatedly the risks associated with the international financial system. Excessive volatility of capital flows exacerbates the structural weaknesses of these economies, especially in the banking system. Thus, policy makers are urged to reassess banking supervision and regulation. However, this cannot go without a clearer understanding of the interaction between banks and other components of the financial structure to define future strategies.

Recent studies show indeed that contractual savings have become important actors of financial systems in developed and also in a handful of emerging economies (e.g., Chile, South Africa). They are also growing at a fast pace in several Latin American countries (e.g., Argentina, Mexico) and demographic evolution may increase the benefits associated to a funded system in other countries. Impavido and Musalem (2000) and Catalan, Impavido and Musalem (2000) show that the development of institutional investors, in particular contractual savings, partly explain the rapid expansion of stock markets over the past 15 years. Impavido, Musalem and Tressel (2001) show moreover that the development and asset allocation of contractual savings have had an independent impact on firms' financing choices after controlling for macroeconomic and firms' characteristics. They identify several channels. In market-based economies, an increase in the proportion of shares in the portfolio of contractual savings leads to a decline in firms' leverage. In bank-based economies, instead, an increase in the size of contractual savings is associated with an increase in leverage and debt maturity in the corporate sector. This suggests that firms are more resilient to refinancing or bankruptcy risks.

However, while the banking system plays a crucial role in most economies as it provides external finance to firms excluded from the securities market, the interaction between contractual savings institutions and banks and its implications on the cost of capital for the firms has not been assessed yet.

Impavido, Musalem and Tressel (2001) propose several mechanisms through which contractual savings interact with the banking sector and that are consistent with their results. First, contractual savings, as competing intermediaries, may increase the efficiency of the banking sector. Underwriting costs may also decrease, thus lowering the cost of access to capital markets. Moreover, banks may respond to more intense competition by concentrating on their core comparative advantage - that is their superior ability to monitor firms - and increase short-term loans. As bank liabilities are liquid, this may reduce the balance sheet mismatch of the banking sector. Second, contractual savings institutions may also be complementary to banks. Indeed, banks may for instance issue long-term securities bought by contractual savings institutions, or the latter could invest in long term bank deposits. As a result, the term-transformation risk in the banking sector may decrease. The development of contractual savings institutions may therefore increase the stability and efficiency of the banking system when adequate regulation and supervision are effective.

This paper provides a first step in providing a better understanding on the impact of contractual savings development on the banking system. First, we provide a discussion of the potential channels through which the development of contractual savings 
institutions might affect the efficiency and stability of the banking system. Second, using bank level data across countries we provide regression analysis on panel data in order to assess the impact on contractual savings on bank efficiency and lending behavior. We concentrate on profitability measures and on term transformation and credit risks indicators.

\section{INTERACTION BETWEEN CONTRACTUAL SAVINGS INSTITUTIONS AND BANKS}

In this section, we discuss the potential mechanisms through which the development of contractual savings institutions might affect the banking system. We want to address two main questions. First, does the development of contractual savings institutions increase or decrease the competitive pressures on banks? In other words, are banks and contractual savings institutions substitute or complementary? Second, does the development of contractual savings institutions enhance the stability of the banking system?

The broad movement of financial liberalization that started in the early eighties has deeply modified the functioning of banking systems in many countries. Increased competitive pressures may increase efficiency of the banking sys tem, but may also increase instability when proper regulation and supervision is not set. Surprisingly, few studies have analyzed the efficiency, profitability and balance sheets of banks on a crosscountry basis ${ }^{1}$. In particular, whereas financial liberalization was often associated to competitive pressures from non-bank financial institutions, there has been, to date, no attempt to analyze both empirically and theoretically the interaction between the banking system and other financial institutions (except the stock market) ${ }^{2}$.

First, we want to assess whether the development of contractual savings institutions has increased the competitive pressures on the banking system, and more particularly how the behavior of banks has been affected, across countries and over time. In doing so, we want to assess the specific impact of contractual savings, after controlling for banks' characteristics, financial sector development, and the macroeconomic environment.

Contractual savings institutions will act as competing suppliers of funds, hence competitive pressure on the banking systems will increase, either indirectly or directly. Contractual savings institutions will indirectly increase competitive pressures because the development of contractual savings institutions is associated to the development and increased liquidity of the capital markets (Impavido and Musalem (2000)). The cost of issuing securities will decrease ${ }^{3}$, hence reducing the market power of banks ${ }^{4}$. Moreover, contractual savings institutions may increase the supply of public information on capital market and have positive spillover effects on the monitoring of borrowers by banks. In

\footnotetext{
${ }^{1}$ See, however, Demirguc-Kunt and Huizinga (1999a, 1999b), Davis and Tuori (2001) and Claessens, Demirguc-Kunt and Huizinga (2001).

${ }^{2}$ Allen and Santomero (1999) claim that the broad movement towards more market finance, that was initiated in the $80 \mathrm{~s}$, has led to a greater importance of non-bank financial intermediation.

${ }^{3}$ Underwriting costs may decrease, as argued by Vittas (1999) and the supply of funds will increase on capital markets.

${ }^{4}$ See Rajan (1992) who analyzes the welfare gains of increasing firms' outside financial opportunities. See also Petersen and Rajan (1995).
} 
addition, the development of contractual savings institutions will directly increase the competitive pressures on the banking system. First, they will compete on the saving side (for instance, in France, the development of life insurance over the past 10 years has implied a significant reallocation of savings from more "classic" banking savings instruments). Second, they will compete on the lending side, either directly or indirectly, by increasing the demand for securities on the primary markets. Hence, we should expect to observe an impact on banks behavior. Competition, however, will be two-dimensional. First, competition will be in price, thus we should expect a decrease in bank net interest margins as contractual savings institutions develop. Second, banks may modify the maturity of their loans. As contractual savings institutions have a comparative advantage in supplying long-term finance ${ }^{5}$, banks may decrease the maturity of their loans ${ }^{6}$. Therefore, one might expect to observe a decrease in the maturity of bank loans.

However, contractual savings institutions may also be complementary to banks. First, as noticed by Demirguc-Kunt and Maksimovic (1996), banks and stock markets may be complementary ${ }^{7}$. Information disclosure requirements and generally the increased transparency associated to capital market development may stimulate the monitoring activity of banks ${ }^{8}$, lowering the credit risk borne by the banking sector ${ }^{9}$; an increase in bank lending and total profitability may be observed as capital markets develop. Second, contractual savings institutions may provide long-term resources to banks, thus reducing the interest rate and liquidity risk in the banking system by limiting the term transformation activity of banks ${ }^{10}$. Therefore the maturity of bank loans may increase if such complementarity effects dominate.

Second, the development of contractual savings institut ions may increase the stability of the banking system, thus reducing systemic risks that may potentially lead to banking crisis $^{11}$. This would be the case if the development of contractual savings institutions reduces the risks borne by the banking sector. First, credit risk may be reduced if the development of contractual savings institutions leads directly or indirectly to an increase in bank monitoring. Second, the development of contractual savings institutions may reduce interest rate risks and liquidity risks associated to the term transformation of assets realized in the banking system. On the one hand, as noticed in the previous paragraph, if

${ }^{5}$ Contractual savings institutions have long-term liabilities.

${ }^{6}$ The maturity choice is also affected by monitoring decisions (Stiglitz and Rey (1993)).

${ }^{7}$ Bank and market finance are complementary also because they finance different segments of the firm population: see Diamond (1991), Bolton and Freixas (2000) among others.

${ }^{8}$ However, the theoretical relation between stock market transparency, liquidity, and monitoring of firms by claimants (banks or investors) is not clear-cut as first illustrated by Grossman and Stiglitz (1984). See also Holmstromand Tirole (1993).

9 Davis (2001) stresses the "multiple avenues" of financial systems by comparing aggregate net flows of bank loans and market debt finance.

${ }^{10}$ Following Diamond and Dybvig (1983), systemic risk in the banking system has been identified as a consequence of maturity transformation and the "sequential service" constraint on bank liabilities; in addition, imperfect information and moral hazard increase this fragility of the banking system (Chen (1999)). Freixas and Rochet (1997) provide a guidebook to microeconomic theories of banking.

11 Increased competitive pressures and financial stability are not incompatible. For a recent theoretical analysis, see for instance Koskela and Stenbacka (2000) who show that loan market competition, which leads to a reduction of lending rates and higher investments without increasing the equilibrium bankruptcy risk of firms. In addition, whether a reduction in term transformation risk in the banking system leads to more or less efficient lending decisions is an empirical question. 
contractual savings institutions are competitors to banks, the latter may indeed respond to competitive pressures by concentrating on their core comparative advantage (associated to narrow banking), -that is their superior ability to monitor firms - and increase shortterm loans. Banks will therefore be able to avoid losses caused either by unexpected increase in short-term interest rates or by sudden withdrawals. On the other hand, if contractual savings institutions provide resources to the banking system (either in the form of loans, deposits, or by buying securities issued by banks), banks will be less subject to liquidity risks for a given level of long-term assets. They may therefore increase the supply of long-term loans ${ }^{12}$. Finally, the recent emerging economies' crisis have stressed the risks associated to short-term capital flows. Excessively volatile capital movements have exacerbated the structural weaknesses of these economies, that were magnified by fragile banking systems ${ }^{13}$. This financial risk is associated to the difficulty (or impossibility) for these economies to borrow abroad in their own currencies, and long-term. One of the solution is to deepen domestic financial system in order to develop domestic sources of long-term finance (see for instance Caballero (2001)), which is the comparative advantage of contractual savings.

The development of contractual savings institutions, given adequate regulation and supervision $^{14}$, may therefore enhance the stability and efficiency of the banking system.

\section{DATA AND EMPIRICAL STRATEGY}

\section{II.A Data}

We use balance sheet and income statement of commercial banks, aggregated by country each year, from the Bankscope data base provided by IBCA. We use an unbalanced sample of banks over the period 1991-2000, in order to maximize the time-series dimension for each country.

The database on contractual savings is taken from Impavido and Musalem (2000), extended for several countries (Argentina, Brazil, India and Mexico). It includes information from different sources (including the OECD institutional investors data 2000 , and national sources) on total assets, financial assets, and allocation of assets for pension funds and insurance companies.

All other macroeconomic variables are obtained from various sources: Datastream, the World Development Indicators, the IMF International Financial Statistics and the Bank for International Settlement for bond markets data.

\footnotetext{
${ }^{12}$ Our results are consistent with this assertion.

${ }^{13}$ See the recent literature, such as Aghion, Banerjee and Bachetta (2000), Caballero and Krishnamurthy (2000), Chang and Velasco (1999), Rodrik and Velasco (1999) and Deckle and Kletzer (2001). For empirical analysis, see Demirguc-Kunt and Detriagache (1997, 1998, 2000) and Harwood et al. eds. (1999). 14 See Barth et al. (2001) for an analysis of the prudential regulation of banks (see also Dewatripont and Tirole (1994)). Generally, La Porta et al. $(1997,1998)$ claim that laws are important determinants of crosscountry differences in firms' external finance choices.
} 


\section{II.B Definition of variables and empirical strategy}

We want to assess the impact of contractual savings institutions on banks' characteristics. More specifically, we analyze: (i) profitability (ii) the maturity structure of loans, (iii) credit risk, and (iv) the structure of liabilities. We focus on pooled (GLS) estimates and panel estimates (GLS with fixed effects). The GLS estimator corrects for heteroschedasticity specific to each panel (country). Fixed effects estimations are important in so far as they control for country specific regulatory and supervision characteristics that may partly explain the cross-country variation of our bank variables ${ }^{15}$ 16 .

The dependent variables that we consider are: (i) net interest margin (NIM), defined as the accounting value of a bank's net interest income over total assets, (ii) profitability (Profit), defined as profit before taxes over total assets ${ }^{17}{ }^{18}$, (iii) loan maturity defined as short-term loans (with maturity less than one year) over total loans (STL), (iv) credit risk proxied by loan loss provisions (over total assets, or over total loans), and (v) the importance of short-term liabilities, proxied by customer + short-term funding (over total assets).

The two first variables describe the profitability of banks, hence proxy for their efficiency. The NIM variable accounts for banking spreads; this variable allows us to assess whether banks pricing behavior may be affected by the development of contractual savings institutions. In addition, the NIM is also affected by the credit risk borne by the banks. The NIM variable is indeed an ex-post measure taking into account the realized default rate. For these reasons, we use also the Profit variable that accounts for all sources of bank profits.

The third variable describes the maturity transformation activity realized in the banking system; more specifically, we want to test whether the development of contractual savings institutions has had an impact on the maturity of bank loans. In other words, do banks increase or decrease long-term lending when contractual savings institutions develop?

The fourth set of variables aim at describing the credit risk borne by the banks. We use two measures: first, loan loss provisioning over total assets is the relevant variable to understand the indirect impact of contractual savings on profitability via the reduction in credit risk. The second variable, loan loss provisions over total loans, roughly describes the risk of the loan portfolio.

\footnotetext{
${ }^{15}$ Fixed effects estimator use the time variation within countries to estimate partial correlations between the dependent and explanatory variables.

${ }^{16}$ We also checked that our results are not affected by the inclusion of time dummies common to all countries.

${ }^{17}$ See for instance Demirgüç-Kunt and Huizinga (1999a, 1999b).

${ }^{18}$ From the income statement, we have the following accounting identity: Profit $=$ NIM + non-interest income / TA - overhead expenses / TA - loan loss provisioning / TA.
} 
We use three sets of explanatory variables: (i) banks' characteristics, (ii) macroeconomic factors, and (iii) financial system characteristics ${ }^{19}$. All the relevant variables are expressed in percentages.

\section{II.B.1 Bank-specific characteristics}

The first bank characteristic is the book value of equity divided by total assets (ETA). Recent studies (see for instance Demirgüç-Kunt and Huizinga (1999a, 1999b) for crosscountry comparisons) show that there exists a positive relationship between bank profitability and capitalization. High capitalization and profitability may indeed reflect a high franchise value (Caprio and Summers (1993)). Moreover, well-capitalized banks may face lower bankruptcy risks, thereby reducing their costs of funding. In addition, we want to control that loan maturity is not explained by the structure of banks liabilities.

The second variable controlling for the structure of bank liabilities is customer and short-term funding over total assets. It includes all short-term and long-term deposits plus other non-deposit short term funding. Again, this variable controls that loan maturity is not driven by the structure of liabilities. This is important in so far as we want to test whether the development of contractual savings institutions has an independent impact on bank loan maturity that is not driven by other bank-specific characteristics.

We include two variables describing the structure of bank activities. The first one is total loans over total assets. The second one is non-interest earnings assets over total assets. Non-interest earnings assets are mainly cash and non-interest earnings deposits at other banks.

Finally, we control for overhead expenses, expressed as a percentage of total assets. This implies that differences between net interest margin and profits before taxes are explained by variations in non- interest income (or taxes and provisions for loan losses).

\section{II.B.2 Macroeconomic factors}

Various macroeconomic factors may affect banks profitability and loan maturity. We use the Log of GDP per capita as a broad measure of economic development. Richer economies have in general more efficient institutions, a better compliance with the legal system in general, and with creditor rights, accounting standards and transparency rules (on the stock market) in particular. Moreover, the inclusion of country fixed effects further controls for unobserved country-specific regulation and supervision. The inflation rate is an indicator of both the government's management of the economy and whether long-term contracting is likely to be widespread. It characterizes also the opportunity cost of holding money. We also include government fiscal balances (\% GDP) to control for the demand for public debt ${ }^{20}$.

\footnotetext{
${ }^{19}$ In order to provide comparable results, we choose explanatory variables similar to those used by Demirgüç-Kunt and Huizinga (1999a, 1999b).

${ }^{20}$ We also used Government debt over GDP. Our main results are not affected. We choose not to report these regressions because of the more limited country coverage.
} 


\section{II.B.3 Financial system characteristics}

The stock market and banking sector variables control that our contractual savings variables are not simply a proxy for the level of development of the financial system and the degree of competition between capital markets and banks ${ }^{21}$.

\section{II.B.3.1 The stock market}

First, we measure the size of stock markets by the stock market capitalization (in percentage of GDP). This variable has been widely used in the recent literature. The ability of the stock market to provide risk diversification opportunities and information also depends on its level of activity and liquidity (Levine and Zervos (1998)). Greater liquidity will encourage investors to acquire stakes in risky firms ${ }^{22}$ and will enhance information acquisition by large investors (Holmstrom and Tirole (1993)). Greater informational content in prices will increase the efficiency of capital allocation, whereas better public information may have a spillover effect on the long-term debt market by reducing initial informational asymmetries, as illustrated in the model in Impavido, Musalem and Tressel (2001). Activity in the stock market is measured by total stock traded over GDP and liquidity is proxied by the turnover ratio, that is the total value traded, in proportion of the stock market capitalization.

\section{II.B.3.2 The banking system}

The degree of competition among banks, and between banks, capital markets and other non-bank financial intermediaries depends on the level of development of the banking system. Moreover, the tendency of banks to engage in long-term lending may also depend on the deepening of the banking sector. We use domestic credit provided by the banking system over GDP as a proxy for the development and soundness of the banking sector.

\section{II.B.3.3 Contractual savings institutions}

The level of development of contractual savings institutions is proxied either by contractual savings financial assets over GDP or the log of contractual savings institutions financial assets over GDP. The Log allows to capture non linearities if for instance the impact of contractual savings development is larger for low initial levels of development than for high initial levels of development. Simple scatter-plots indeed suggest the existence of such non-linearities for NIM, profits, and loan maturity.

\section{II.B.4 Empirical strategy}

We start with summary statistics of the variables defined in the previous paragraph. A detailed description of the evolution of contractual savings institutions over the period studied in our sample can be found in Impavido, Musalem and Tressel (2001). Next, we

\footnotetext{
${ }^{21}$ Whereas the level of development and characteristics of capital markets (and the size of the banking sector) may affect bank profitability, recent studies suggest that financial structure per se (that is the relative importance of capital markets and the banking sector) has not additional impact (see DemirgucKunt and Huizinga (1999b), Demirguc-Kunt and Levine (1999) and Beck et al. (2000)).

${ }^{22}$ And make efficient restructuring decisions, see Maug (1998) for a theoretical argument.
} 
compute simple correlations between the variables. These simple statistics show a strong correlation between the development of contractual savings institutions and banks characteristics. Finally, we provide panel data analysis (GLS without and with fixed effect estimates, with a correction for heteroschedasticity). Our bank level data are aggregated at the country level for each year. The intersection of the various data set (Bankscope, Institutional Investors Data base, and World Bank Indicators) provide a sample of approximately 200 observations, and 8 years at best per country.

\section{EMPIRICAL RESULTS}

\section{III.A Descriptive statistics}

Table 1 presents the sample of countries that are included in our contractual savings database, and the total number of banks available for each country. We have data for 34 countries, including 13 emerging economies (Argentina, Brazil, Chile, Hungary, India, Korea, Malaysia, Mexico, Singapore, South Africa, Sri Lanka, Thailand and Turkey). The contractual savings data include information on total financial assets and portfolio composition for pension funds and insurance companies (in particular corporate stocks), except for 6 countries for which we have no information on equity investments (Austria, Brazil, France, Japan, Spain, and Turkey). The Bankscope database has a very comprehensive coverage in most countries, with banks included roughly accounting for $90 \%$ of total banking assets (Demirguc-Kunt and Huizinga (1999)).

Table 2 provides the definition of the variables used in the regressions. As described in detail in Impavido, Musalem and Tressel (2001), there has been a spectacular increase ${ }^{23}$ in the total assets managed by pension funds and life insurance companies, ${ }^{24}{ }^{25}$ relative to GDP. Expressed in rate of growth, the increase is even more impressive. Contractual savings financial assets, relative to GDP, have been growing at an average annual rate of $17.7 \%, 3.4 \%, 6.9 \%, 6.0 \%, 7.9 \%, 8.99 \%$ and $4.6 \%$ respectively in France, Germany, South Africa, the United States, the United Kingdom, Chile and Korea. As shown by Impavido and Musalem (2000) and discussed also in Impavido, Musalem and Tressel (2001), this development has been similar, in term of growth, to the development of capital markets, and may partly explain this evolution.

Table 3 provides simple descriptive statistics while Table 4 displays the correlation between the main variables. Net interest margins display some slight differences between countries, when averaged over the period, with a maximum value of $7.71 \%$ for Turkey and a minimum of $1.05 \%$ in Switzerland. Argentine banks are the most capitalized, on average (14.62\% of total assets), while Belgium ones are the least capitalized (3.64\%). Banks have the highest proportion of loans in their assets $(72.7 \%)$ in New Zealand, while those in Brazil have the lowest proportion of loans (33.9\%). The maturity of loans exhibits also significant differences (we have the information on loan

${ }^{23}$ Singapore is the only country in which contractual savings assets decreased relative to GDP.

${ }^{24}$ Musalem and Impavido (2000) show, on this sample of countries, that this explosion of contractual savings institutions may partly explain the rapid growth of stock markets over the last 15 years.

${ }^{25}$ In France, where pension funds are underdeveloped, the life insurance industry exploded at the beginning of the 90 s as a result of strong fiscal incentives to save in life-insurance products (these savings were exempt of taxes). 
maturity structure only in 15 countries): $92.5 \%$ of Greek banks loans are a maturity below 1 year while on the contrary almost $80 \%$ of bans by Belgium banks have a maturity above 1 year. Table 4 finally shows that there is a strong negative correlation between the net interest margin and the log of contractual savings financial assets (\%GDP). Note that the correlation is also negative and significant if we simply consider contractual savings financial assets over GDP. The proportion of short-term loans in total bank loans is also strongly negatively correlated with LogcsfaGDP suggesting that the development of contractual savings institutions is associated with an increase in loan maturity. The structure of liabilities does not seem to be significantly correlated with the development of contractual savings ${ }^{26}$. Finally, credit risk seems to be negatively correlated with the development of contractual savings institutions. Note the large crosscountry differences: the top 4 countries in term of credit risk (LLTA) are Hungary (2.36\%), Argentina (1.56\%), Thailand (1.18\%) and Brazil $(1.16 \%)$, while banks face the lowest credit risk in Germany (0.06\%), Austria (0.10\%), Belgium (0.21\%) and Ireland $(0.24 \%)$. In the former group, contractual savings financial assets are $4.3 \%$ of GDP on average, and $29.6 \%$ on average in the latter group. This suggests that contractual savings may have some explanatory power for such cross-country differences. The econometric analysis will confirm its robustness. This is consistent with conclusions drawn by Impavido, Musalem and Tressel (2001). Finally, Figures 1, 2 and 3 illustrate the correlation between maturity of loans, net interest margin and credit risk, respectively, with the development of contractual savings.

These simple statistics neither account for banks' characteristics, nor allow one to conclude that the correlations are not the result of the correlation with stock market and banks characteristics. In the next section, we provide a simple econometric analysis that confirms that the correlation between banks' profitability, loan policy and the activity of institutional investors is not merely a function of banks' characteristics and other macroeconomic factors.

\section{III.B Regression results}

Table 5, 6, 7, 8, 9 and 10 report regression results respectively for (1) the net interest margin, (2) the profit rate, (3) the maturity of bank loans, (4) the credit risk (loan loss provisions over total assets), (5) the credit risk proxied by loan loss provisions over total loans, and (6) the structure of liabilities (customer and short-term funding over total assets). For each dependent variable, we report OLS and within (fixed effect) estimates. In each case, time dummies are included (not displayed in the tables), and we include the full set of control variables described in the previous sections. Moreover, we controlled for the potential simultaneity bias between the dependent variable and the contractual savings variable in two ways: first, we use the lagged contractual savings variable; second, we instrumented the contractual saving variable by its lagged value and a set of lagged macroeconomic indicators (see Impavido and Musalem (2000)). This also suggests that causality - if any - is more likely to go from contractual savings development to bank profitability and loan maturity. The lag may also simply reflect the time adjustment for the impact of contractual savings to materialize.

\footnotetext{
${ }^{26}$ On the contrary, econometric analysis will show a strong negative correlation between short-term funds and contractual savings development.
} 
Table 5 displays the results of the net interest margin regressions. First, the NIM is positively correlated with the capitalization ratio, which is consistent with previous studies (see Demirguc-Kunt and Huizinga (1999)). It is also significantly and positively correlated with the structure of assets, the sources of funds and overhead expenses. Note however that the last correlation probably simply reflects the financial statement accounting identity. Second, it is negatively correlated with stock market liquidity, but positively correlated with stock market activity. Government fiscal balances are negatively correlated with net interest margin, possibly reflecting macroeconomic uncertainties. Inflation and real GDP per capital growth are positively correlated with NIM when considering cross-country variations (OLS) but negatively correlated with NIM when considering within variations (fixed effects). Third, the level of development of contractual savings institutions (LogesfaGDP) is negatively associated with net interest margin $^{27}$ when concentrating on cross country variations (however within country variation has not significant impact): We have a logarithmic relation between contractual savings development and net interest margin; this suggests that the magnitude of the impact depends on the initial development of contractual savings institutions. The impact is large at low initial level of contractual savings development, and it decreases as contractual savings institutions develop. Therefore, our results are consistent with the initial hypothesis that the development of contractual savings institutions is associated to increased competitive pressures in the banking system, leading banks to reduce the spreads between loan and deposit rates.

Table 6 displays the results of the profit regressions. Note now that the correlation between contractual savings development and bank profits is reversed. Indeed, while the OLS regression does not show any significant correlation, the fixed effect estimation provides a positive and significant correlation between contractual savings development and bank profitability. While banks tend to choose lower spread when contractual savings institutions are more developed, the total impact on profit is surprisingly positive. In Tables 8 and 9, we show that the impact is likely to go through a reduction in credit risk.

Loan maturity regressions are summarized in Table 7 (these estimations are realized on a subset of 14 countries for which we have the information). Note that, given the bank level control variables included in the regressions, the results obtained on the LogcsfaGDP variable do not reflect modifications in the structure of assets or liabilities of the banks. First, standard measures of financial development do not seem to explain the loan maturity, while GDP growth and inflation do have a significant effect. Second, the level of development of contractual savings institutions has a positive and significant effect on loan maturity. Given the discussion in the second section, this suggests that, even if banks seem to face higher competitive pressures when contractual savings institutions develop (thus reducing interest spreads), they do not reduce the maturity of loans (in other word they do not seem to concentrate on their core activity). On the

27 The correlation is weaker if we simply take csfaGDP; this suggests that non linearities are probably important. 
contrary, there seems to be a complementarity between the two institutions when concentrating on the loan maturity dimension ${ }^{28}$.

In Tables 8 and 9, we show moreover that there is a strong negative correlation between credit risk borne by the banking system and the level of development of contractual savings institutions. It is worthwhile underlying that this strong result does not reflect cross-country differences, for instance the level of economic development ${ }^{29}$. This result complements the conclusions of Impavido, Musalem and Tressel (2001) who show that the corporate sector is more resilient to various shocks when contractual savings institutions are more developed or invest more on the stock exchange.

Finally, we show in Table 10 that, within countries, the development of contractual savings implies a reduction in short-term liabilities of the banking sector. Hence, this result is also consistent with complementarity between banks and contractual savings institutions.

\section{CONCLUDING REMARKS}

This paper is a first attempt at assessing the interaction between the banking system and contractual savings institutions that have rapidly developed over the past 20 years in many countries. We show that the development of contractual saving is associated with a more efficient banking system. Moreover, our results strongly support the argument that the banking system is more resilient to liquidity and credit risks when contractual savings institutions are more developed. They are consistent with the conclusions drawn by Impavido, Musalem and Tressel (2001) concerning firms' financing patterns.

\footnotetext{
${ }^{28}$ For various aspects of the role of long-term finance, see the discussion in Impavido, Musalem and Tressel (2001).

${ }^{29}$ Indeed, we obtain the same result in the fixed effect estimations.
} 


\section{REFERENCES}

[1] Aghion, P., Bachetta, P., and A. Banerjee (2000), Currency Crisis and Monetary Policy in an Economy with Credit Constraints, Harvard University, mimeo.

[2] Allen, F., and Santomero, A. M. (1998), The Theory of Financial Intermediation, Journal of Banking and Finance, 21, 1461-1485.

[3] Barth, James, Gerard Caprio and Ross Levine (2001) Bank Regulation and Supervision: What Works and What Doesn't, World Bank, mimeo.

[4] Beck 1., Di mirguc-Kunt, A., Levine, R., and V. Maksimovic (2000), Financial Strucuur and Economic Development: Firm, Industry and Country Evidence, World Bank Po،icy Research Working Paper, No. 2423.

[5] Bolton, P., and X. Freixas (2000) Equity, Bonds, and Bank Debt: Capital Structure and Financial Market Equilibrium under Asymmetric Information, Journal of Political Economy, vol.108, No.2.

[6] Caballero Ricardo J. (2001) Macroeconomic Volatility in Latin America: a View and Three Case Studies, mimeo MIT.

[7] Caballero Ricardo J. and Arvind Krishnamurthy (2000) Dollarization of Liabilities: Underinsurance and Domestic Financial Development, mimeo MIT.

[8] Caprio, Gerard, Jr. and Asli Demirguc-Kunt (1997) The Role of Long Term Finance: Theory and Evidence, Policy Research Department, The World Bank.

[9] Caprio, G. , and L. Summers (1993) Finance and its Reform, Beyond LaissezFaire, World Bank Policy Research Paper 1171.

[10] Catalan, M., Impavido G., and A. R. Musalem (2000) Contractual Savings or Stock Market Development: Which Leads? Journal of Applied Social Science Studies, 120(3): 445-87. Paper can also be downloaded from the World Bank Pension Primer Series at http://www.worldbank.org/pensions

[11] Chang, R., and A. Velasco (1999), Liquidity Crisis in Emerging Markets - Theory and Evidence, NBER Working Paper, No 7272.

[12] Chen, Yehning (1999) Banking Panics: The Role of the First-Come, First-Served Rule and Information Externalities, Journal of Political Economy, Vol. 107, No.5.

[13] Claessens, S., Demirguc-Kunt, A., and H. Huizinga (2001), How Does Foreign Entry Affect Domestic Bank Markets?, Journal of Banking and Finance, No.25, 891-911.

[14] Davis, E. Philip (2001) Multiple Avenues of Intermediation, Corporate Finance and Financial Stability, IMF Working Paper.

[15] Davis, E. Philip and Klaus Tuori (2001) The Changing Structure of Banks' Income, an Empirical Investigation.

[16] Deckle, R. and K. Kletzer (2001) Domestic Bank Regulation and Financial Crisis: Theory and Empirical Evidence from East Asia, NBER working paper 8322. 
[17] Demirguc-Kunt, Asli and Enrica Detragiache (1997) The Determinants of Banking Crisis: Evidence from Developed and Developing Countries, mimeo World Bank.

[18] Demirguc-Kunt, Asli and Enrica Detragiache (1998) Financial Liberalization and Financial Fragility, mimeo World Bank.

[19] Demirguc-Kunt, Asli and Enrica Detragiache (2000) Does Deposit Insurance Increase Banking System Stability? An Empirical Investigation, mimeo World Bank.

[20] Demirguc-Kunt, Asli and Harry Huizinga (1999a) Determinants of Commercial Bank Interest Margins and Profitability: some International Evidence, The World Bank Economic Review, vol.13 No.2, 379-408.

[21] Demirguc-Kunt, Asli and Harry Huizinga (1999b) Financ ial Structure and Bank Profitability, mimeo World Bank.

[22] Demirguc-Kunt, Asli, and Ross Levine (1999) Bank-Based and Market Based Financial Systems: Cross-Country Comparisons, mimeo, World Bank.

[23] Demirguc-Kunt, Asli, and Vojislav Maksimovic (1996) Stock Market Development and Financing Choices of Firms, The World Bank Economic Review, vol.10, no.2.

[24] Dewatripont, M., and J. Tirole, (1994) The Prudential Regulation of Banks, The MIT Press.

[25] Diamond, D., and Dybvig (1983), Bank Runs, Deposit Insurance, and Liquidity, Journal of Political Economy, 91, 401-419.

[26] Diamond, Douglas W. (1991) Monitoring and Reputation: The Choice between Bank Loans and Directly Placed Debt, Journal of Political Economy, vol. 99, no. 4.

[27] Freixas, Xavier, and Jean-Charles Rochet (1997) Microeconomics of Banking, The MIT Press.

[28] Greene William H. (1990) Econometric Analysis, Second Edition, Prentice Hall.

[29] Grossman, S. and J. Stiglitz, (1984) On the impossibility of informationally efficient markets, American Economic Review, 70, 393-408.

[30] Harwood, A., Litan, R., and M. Pomerleano (eds.) Financial Markets and Development - The Crisis in Emerging Markets. 1999, Brookings Institution Press, Washington D.C.

[31] Holmstrom, Bengt, and Jean Tirole (1993) Market Liquidity and Performance Monitoring, Journal of Political Economy, vol. 101, no. 4.

[32] Impavido, G., and A. R. Musalem (2000), Contractual Savings, Stock and Asset Markets, World Bank Policy Research Paper 2490.

[33] Impavido, Gregorio, Musalem, Alberto R., and Thierry Tressel (2001), Contractual Savings, Capital Markets and Firms' Financing Choices, World Bank Policy Research Paper 2186. 
[34] Institutional Investors Statistical Yearbook OECD 2000 Edition.

[35] Koskela, E., and R. Stenbacka (2000) Is There a Tradeoff between Bank Competition and Financial Fragility? Journal of Banking and Finance, No.24, 18531873.

[36] La Porta, Rafael, Florencio Lopezde-Silanes, Andrei Shleifer, and Robert W. Vishny (1997) Legal Determinants of External Finance, Journal of Finance, no.52.

[37] La Porta, Rafael, Florencio Lopezde-Silanes, Andrei Shleifer, and Robert W. Vishny (1998) Law and Finance, Journal of Political Economy, no.106.

[38] Levine, Ross (1997) Financial Development and Economic Growth: Views and Agenda, Journal of Economic Literature, June.

[39] Levine,R. and Zervos, S., (1998) Stock Markets and Economic Growth, The American Economic Review, LXXXVIII, 537-58.

[40] Maug, E., (1998) Large Shareholders as Monitors: Is There a Trade-Off between Liquidity and Control, The Journal of Finance.

[41] OECD, (2000) Institutional Investors in La tin America.

[42] Petersen, M., and R. Rajan (1995) The Effect of Credit Market Competition on Lending Relationships, The Quarterly Journal of Economics.

[43] Rajan, R. (1992), Insiders and Outsiders: The Choice between Informed and Arm's-length Debt, Journal of Finance, 47, 1367-1400.

[44] Rey, Patrick and Joseph E. Stiglitz (1993) Short-term Contracts as a Monitoring Device, NBER Working Paper, no. 4514.

[45] Rodrik, D., and Andres Velasco (1999) Short-term Capital Flows, mimeo Harvard University.

[46] Shleifer, Andrei, and Robert W. Vishny (1997) A Survey of Corporate Governance, Journal of Finance 52.

[47] Stulz, Rene, (2000) Does Financial Structure Matter for Economic Growth? A Corporate Finance Perspective, mimeo.

[48] Vittas Dimitri (1999) Pension Reform and Financial Markets, Harvard Institute for International Development, Development Discussion Paper no. 697.

[49] Vittas, Dimitri (2000) Pension Reform and Capital Market Development: Feasiblity and Impact Preconditions. World Bank Policy Research Paper no. 2414. 
Gregorio Impavido, Alberto R. Musalem, and Thierry Tressel

APPENDIX A

Table 1: The Sample

\begin{tabular}{|c|c|c|c|c|c|c|c|c|}
\hline Cos & county & $\begin{array}{l}\text { Madmum } \\
\text { Semplo } \\
\text { Sim } \\
\text { (poryoed) }\end{array}$ & \multicolumn{2}{|c|}{ Pensionfunds } & \multicolumn{2}{|c|}{ Insurance Comperios } & \multicolumn{2}{|c|}{ If harance Compentss } \\
\hline 1 & ARCENINA & 110 & $Y \in$ & Yes & Yes & $Y \in \infty$ & $N$ & $N$ \\
\hline 2 & ALSTRALA & 87 & Yes & Yes & Yes & Yes & Yes & Yes \\
\hline 3 & ALSTRA & 149 & Yes & $\mathrm{Nb}$ & Yes & No & Yes & $\mathrm{No}$ \\
\hline 4 & BAGM & 110 & Yes & Yes & Yes & Yes & Yes & Yes \\
\hline 5 & BRAZ & 158 & $Y \in S$ & Yes & Yes & Yes & N & No \\
\hline 6 & CANADA & 72 & Yes & Yes & Yes & Yes & Yes & Yes \\
\hline 7 & OHE & 36 & $Y_{E}$ & Yes & $Y_{E S}$ & Yes & $Y \in$ & Yes \\
\hline 8 & DENAFK & 106 & $Y \in$ & YES & Yes & Yes & $Y \in$ & $Y \in$ \\
\hline 9 & FNAND & 17 & $Y_{E}$ & Yes & Yes & Yes & 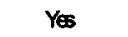 & Yes \\
\hline 10 & FRANOE & 516 & Yes & $\mathrm{Nb}$ & Yes & $\mathrm{Nb}$ & Yes & No \\
\hline 11 & GANANY & 2111 & Ys & Yes & Yes & Yes & Yes & Yes \\
\hline 12 & $G P O E$ & 26 & Yes & Yes & Yes & Yes & Yes & Yes \\
\hline 13 & HNGARY & 31 & Yes & Yes & Yes & Yes & Yes & $Y e s$ \\
\hline 14 & NDA & 85 & Yes & Yes & Yes & Yes & Yes & Yes \\
\hline 15 & REAND & 52 & Yes & YES & $Y e s$ & Yes & $Y \in s$ & Yes \\
\hline 16 & TALY & 505 & Yes & Yes & Yes & YES & Yes & Yes \\
\hline 17 & JAPAN & 213 & Yes & No & Yes & $\mathrm{Nb}$ & Yes & $\mathrm{Nb}$ \\
\hline 18 & KOFEA(SOMH) & 56 & Yes & Yes & Yes & Yes & Yes & Yes \\
\hline 19 & MALAYSA & 84 & Yes & Yes & Yes & Yes & $Y \in S$ & Yes \\
\hline 20 & NENOO & 47 & YES & Yes & YES & Yes & Yes & $\mathrm{Nb}$ \\
\hline 27 & NEIHERANDS & 75 & Yes & Yes & $Y e s$ & Yes & $Y \in$ & Yes \\
\hline 22 & NEWZEALAND & 18 & $Y \in$ & Yes & $Y \in S$ & Yes & Yes & Yes \\
\hline$\overline{23}$ & NORNAY & 47 & $Y \in$ & Yes & Yes & Yes & $Y \in$ & Yes \\
\hline 24 & PORIUGA & 48 & Yes & Yes & Yes & Yes & Yes & Yes \\
\hline 25 & SNGAPCE & 59 & Yes & Yes & Yes & Yes & Yes & YES \\
\hline$\overline{\mathbf{2 0}}$ & SOUTHAFXA & 67 & Yes & Yes & Yes & Yes & Yes & $Y \in$ \\
\hline 27 & SPAN & 171 & Yes & $\mathrm{Nb}$ & $Y e s$ & $\mathbf{N}$ & Yes & No \\
\hline 28 & SPLANA & 12 & Ys & Yes & Yes & Yes & YES & $Y \in S$ \\
\hline $\overrightarrow{2}$ & SNEAR & $\mathbf{3 0}$ & Yes & Yes & Yes & $Y e s$ & $Y \in$ & Yes \\
\hline 30 & SNTZERAND & 381 & $Y e$ & Yes & Yes & Yes & Yes & Yes \\
\hline 31 & THALAN & 34 & Yes & YES & Yes & Yes & $Y e s$ & Yes \\
\hline 32 & TUAEY & 34 & $Y \in$ & No & $Y \in S$ & No & Yes & Nb \\
\hline 33 & UNIEDKNGDOM & 398 & YES & $Y \in$ & $Y$ & Yes & Yes & $Y_{E S}$ \\
\hline 34 & UNIEDSTATES & 1153 & Yes & Yes & Yes & Yes & Yes & Yes \\
\hline
\end{tabular}


Gregorio Impavido, Alberto R. Musalem, and Thierry Tressel

Table 2: Definition of Variables

VARIABLE

Banks ' Characteristics

Net interest Margin (NIM)

Profitability (Profit)

Capitalization (ETA)

Structure of Assets ( LTA )

Sources of Funds (STFTA)

Overhead (OTTA)

Maturity of Loans (STL)

Non Earnings Assets (CTA)

Credit Risk A (LLTA)

Credit Risk B (LLLN)

Macroeconomic Factors

Inflation ( INF )

GDP growth

$\log (G D P / c a p)$

Budget Balance

Financial System Development

Credit to Private Sector (ec2)

Stock Market Capitalization (ec12)

Stock Market Activity (ec19)

Turnover Ratio (TOR)

Contractual Savings insitutions

CS Development (\% GDP)

(csfaGDP or Log (csfaGDP))

\section{DEFINITION}

\author{
(Interest Income - Interest Expenses) / Total Assets \\ Total Profit before Taxes / Total Assets \\ Equity / Total Assets \\ Loans / Total Assets \\ Customer \& Shortterm Funding / Total Assets
}

Overhead Expenses - Tax / Total Assets

Short-term Loans (maturity less than 1 year) / Totat Loans

Non Earnings Assets / Total Assets

Loan Loss Provisions / Total Assets

Loan Loss Provisions / Total Loans

Consumer Price Index Rate of Growth

rate of growth of GOP, adjusted for inflation

Ln (GDP/capita) (constant US \$)

Central Government Budget Surplus (t) / Deficit (-) (\% GDP)

Credit to Private Sector by Financial Intermediaries ( \% GDP)

Stock Market Capitalization ( \% GDP)

Value Traded ( \% GDP)

Value Traded( \% Capitalization )

Pension Funds + Life Insurance* Total Financial Assets (\% GDP)

* : Life + Non Life Insurance for Argentina and Brazil 
Gregorio Impavido, Alberto R. Musalem, and Thierry Tressel

Table 3: Summary Statistics (period average )

\begin{tabular}{|c|c|c|c|c|c|c|c|c|c|c|c|c|c|c|c|}
\hline Country & $\begin{array}{c}\text { ETA } \\
\% \\
\end{array}$ & $\begin{array}{r}\text { LTA } \\
\% \\
\end{array}$ & $\begin{array}{c}\text { STFTA } \\
\% \\
\end{array}$ & $\begin{array}{c}\mathrm{NIM} \\
\%\end{array}$ & $\begin{array}{c}\text { OTTA } \\
\% \\
\end{array}$ & $\begin{array}{c}\text { CTA } \\
\% \\
\end{array}$ & $\begin{array}{c}\text { Profit } \\
\% \\
\end{array}$ & $\begin{array}{c}\text { STL } \\
\% \\
\end{array}$ & $\begin{array}{c}\text { ec2 } \\
\% \\
\end{array}$ & $\begin{array}{c}\theta c 12 \\
\% \\
\end{array}$ & $\begin{array}{c}\text { ect9 } \\
\%\end{array}$ & $\begin{array}{c}\text { TOR } \\
\% \\
\end{array}$ & $\begin{array}{c}\text { esfaGDP } \\
\% \\
\end{array}$ & $\begin{array}{c}\text { Bud Bal. } \\
\% \text { GDP }\end{array}$ & $\begin{array}{c}\text { LLTA } \\
\% \\
\end{array}$ \\
\hline $\begin{array}{l}\text { Argentina } \\
\text { Australia }\end{array}$ & $\begin{array}{c}14.62 \\
6.45\end{array}$ & $\begin{array}{l}54.59 \\
66.91\end{array}$ & $\begin{array}{l}75.62 \\
71,80\end{array}$ & $\begin{array}{l}3.99 \\
2.36\end{array}$ & $\begin{array}{l}6.50 \\
2.26\end{array}$ & $\begin{array}{l}3.06 \\
0.76\end{array}$ & $\begin{array}{l}1.18 \\
1.38\end{array}$ & $\begin{array}{l}\text { NA } \\
\text { NA }\end{array}$ & $\begin{array}{l}28.06 \\
83.61\end{array}$ & $\begin{array}{l}16.34 \\
78.69\end{array}$ & $\begin{array}{c}4.25 \\
31.46\end{array}$ & $\begin{array}{l}30.27 \\
38.95\end{array}$ & $\begin{array}{l}2.61 \\
58.88\end{array}$ & $\begin{array}{l}-1.10 \\
-0.99\end{array}$ & $\begin{array}{l}1.56 \\
0.34\end{array}$ \\
\hline Austria & 5.86 & 43.81 & 67.39 & 1.35 & 1.26 & 1.70 & 0.51 & NA & 125.62 & 13.87 & 7.16 & 54.12 & 18.70 & 3.52 & 0.10 \\
\hline $\begin{array}{l}\text { Belglum } \\
\text { Brazll }\end{array}$ & $\begin{array}{l}3.64 \\
8.18\end{array}$ & $\begin{array}{l}38.14 \\
33.95\end{array}$ & $\begin{array}{l}85.52 \\
62.55\end{array}$ & $\begin{array}{l}1.42 \\
6.55\end{array}$ & $\begin{array}{l}1.38 \\
9.17\end{array}$ & $\begin{array}{l}0.32 \\
1.94\end{array}$ & $\begin{array}{l}0.60 \\
0.86\end{array}$ & $\begin{array}{c}20.65 \\
N A\end{array}$ & $\begin{array}{c}138.97 \\
74.84\end{array}$ & $\begin{array}{l}49.77 \\
23.47\end{array}$ & $\begin{array}{l}10.09 \\
13.69\end{array}$ & $\begin{array}{l}18.15 \\
56.27\end{array}$ & $\begin{array}{c}24.53 \\
8.15\end{array}$ & $\begin{array}{l}-4.35 \\
-4.67\end{array}$ & $\begin{array}{l}0.21 \\
1.16\end{array}$ \\
\hline $\begin{array}{l}\text { Canada } \\
\text { Switzerland }\end{array}$ & $\begin{array}{l}5.69 \\
5.48\end{array}$ & $\begin{array}{l}59.81 \\
44.78\end{array}$ & $\begin{array}{l}81.09 \\
67.75\end{array}$ & $\begin{array}{l}2.05 \\
1.05\end{array}$ & $\begin{array}{l}1.91 \\
2.02\end{array}$ & $\begin{array}{l}1.17 \\
2.31\end{array}$ & $\begin{array}{l}0.96 \\
0.61\end{array}$ & $\begin{array}{c}\text { NA } \\
62.25\end{array}$ & $\begin{array}{r}96.59 \\
180.83\end{array}$ & $\begin{array}{l}73.17 \\
156.85\end{array}$ & $\begin{array}{l}37.40 \\
121.95\end{array}$ & $\begin{array}{l}48.85 \\
71.71\end{array}$ & $\begin{array}{l}60.84 \\
96.69\end{array}$ & $\begin{array}{r}3.80 \\
-1.22\end{array}$ & $\begin{array}{l}0.53 \\
0.34\end{array}$ \\
\hline Chile & 6.31 & 49.68 & 59.74 & 2.69 & 2.26 & 7.76 & -0.02 & NA & 64.89 & 96.73 & 9.27 & 9.37 & 42.23 & 1.84 & 0.34 \\
\hline $\begin{array}{l}\text { Germany } \\
\text { Denmaxk }\end{array}$ & $\begin{array}{l}3.65 \\
7.15\end{array}$ & $\begin{array}{l}55.73 \\
65.34\end{array}$ & $\begin{array}{l}62.22 \\
45.49\end{array}$ & $\begin{array}{l}1.46 \\
2.18\end{array}$ & $\begin{array}{l}1.08 \\
1.18\end{array}$ & $\begin{array}{l}1.09 \\
0.69\end{array}$ & $\begin{array}{l}0.56 \\
0.78\end{array}$ & $\begin{array}{l}38.04 \\
26.16\end{array}$ & $\begin{array}{c}126.58 \\
57.62\end{array}$ & $\begin{array}{l}32.96 \\
40.56\end{array}$ & $\begin{array}{l}35.10 \\
\$ 8.41\end{array}$ & $\begin{array}{c}105.37 \\
46.56\end{array}$ & $\begin{array}{l}21.82 \\
52.06\end{array}$ & $\begin{array}{r}-1.78 \\
-0.93\end{array}$ & $\begin{array}{l}0.06 \\
0.85\end{array}$ \\
\hline $\begin{array}{l}\text { Spain } \\
\text { Finland }\end{array}$ & $\begin{array}{l}6.15 \\
5.52\end{array}$ & $\begin{array}{l}48.96 \\
48.80\end{array}$ & $\begin{array}{l}76.81 \\
74.03\end{array}$ & $\begin{array}{l}2.70 \\
1.73\end{array}$ & $\begin{array}{l}1.99 \\
1.76\end{array}$ & $\begin{array}{l}2.84 \\
0.94\end{array}$ & $\begin{array}{l}1.16 \\
0.05\end{array}$ & $\begin{array}{c}\text { NA } \\
31.73\end{array}$ & $\begin{array}{c}105.55 \\
72.74\end{array}$ & $\begin{array}{l}41.13 \\
69.25\end{array}$ & $\begin{array}{l}46.35 \\
24.62\end{array}$ & $\begin{array}{l}86.99 \\
33.08\end{array}$ & $\begin{array}{l}12.98 \\
43.56\end{array}$ & $\begin{array}{l}-4.78 \\
-8.00\end{array}$ & $\begin{array}{l}0.49 \\
0.75\end{array}$ \\
\hline France & 4.74 & 41.53 & 70.24 & 1.40 & 1.53 & 0.59 & 0.41 & NA & 103.35 & 46.29 & 24.34 & 51.16 & 29.79 & -4.47 & 0.51 \\
\hline $\begin{array}{l}\text { United Kingdom } \\
\text { Greace }\end{array}$ & $\begin{array}{l}5.32 \\
4.80\end{array}$ & $\begin{array}{l}52.54 \\
40.51\end{array}$ & $\begin{array}{l}75.55 \\
77.95\end{array}$ & $\begin{array}{l}2.03 \\
1.65\end{array}$ & $\begin{array}{l}2.01 \\
1.74\end{array}$ & $\begin{array}{l}1.91 \\
7.51\end{array}$ & $\begin{array}{l}1.07 \\
1.21\end{array}$ & $\begin{array}{l}28.74 \\
92.53\end{array}$ & $\begin{array}{l}122.62 \\
95.00\end{array}$ & $\begin{array}{c}135.95 \\
38.28\end{array}$ & $\begin{array}{l}54.89 \\
25.71\end{array}$ & $\begin{array}{l}39.50 \\
41.54\end{array}$ & $\begin{array}{c}132.21 \\
8.45\end{array}$ & $\begin{array}{r}3.71 \\
-8.37\end{array}$ & $\begin{array}{l}0.42 \\
0.31\end{array}$ \\
\hline $\begin{array}{l}\text { Hungany } \\
\text { Indla }\end{array}$ & $\begin{array}{l}4.41 \\
6.24\end{array}$ & $\begin{array}{l}38.15 \\
41.13\end{array}$ & $\begin{array}{l}55.58 \\
64.27\end{array}$ & $\begin{array}{l}\mathbf{2 . 3 5} \\
\mathbf{3 . 4 6}\end{array}$ & $\begin{array}{l}2.61 \\
1.80\end{array}$ & $\begin{array}{l}16.53 \\
0.41\end{array}$ & $\begin{array}{l}-0.81 \\
1.78\end{array}$ & $\begin{array}{c}54.94 \\
\text { NA }\end{array}$ & $\begin{array}{l}80.26 \\
47.98\end{array}$ & $\begin{array}{l}13.59 \\
31.60\end{array}$ & $\begin{array}{c}9.62 \\
11.15\end{array}$ & $\begin{array}{l}39.94 \\
36.48\end{array}$ & $\begin{array}{l}2.41 \\
7.23\end{array}$ & $\begin{array}{r}-4.35 \\
-2.63\end{array}$ & $\begin{array}{l}2.36 \\
0.28\end{array}$ \\
\hline Iroland & 7.27 & 56.06 & 77.58 & 2.09 & 1.62 & 1.75 & 1.17 & 27.20 & 69.98 & 28.57 & 32.81 & 106.46 & 53.66 & -1.33 & 0.24 \\
\hline $\begin{array}{l}\text { Italy } \\
\text { Japan }\end{array}$ & $\begin{array}{l}6.16 \\
4.44\end{array}$ & $\begin{array}{l}49.35 \\
62.32\end{array}$ & $\begin{array}{l}66.48 \\
72.46\end{array}$ & $\begin{array}{l}2.30 \\
1.22\end{array}$ & $\begin{array}{l}2.05 \\
1.19\end{array}$ & $\begin{array}{l}0.53 \\
0.70\end{array}$ & $\begin{array}{l}0.69 \\
0.05\end{array}$ & $\begin{array}{l}57.05 \\
44.05\end{array}$ & $\begin{array}{c}97.33 \\
251.86\end{array}$ & $\begin{array}{l}26.21 \\
74.17\end{array}$ & $\begin{array}{l}15.77 \\
26.78\end{array}$ & $\begin{array}{l}49.67 \\
36.61\end{array}$ & $\begin{array}{l}10.16 \\
29.59\end{array}$ & $\begin{array}{l}-7.75 \\
0.16\end{array}$ & $\begin{array}{l}0.47 \\
0.80\end{array}$ \\
\hline $\begin{array}{l}\text { Korea } \\
\text { Sr Lanka }\end{array}$ & $\begin{array}{l}5.22 \\
6.80\end{array}$ & $\begin{array}{l}52.25 \\
44.86\end{array}$ & $\begin{array}{l}7274 \\
54.15\end{array}$ & $\begin{array}{l}1.50 \\
3.05\end{array}$ & $\begin{array}{l}1.68 \\
2.63\end{array}$ & $\begin{array}{l}2.24 \\
7.46\end{array}$ & $\begin{array}{l}0.07 \\
1.40\end{array}$ & $\begin{array}{l}\text { NA } \\
\text { NA }\end{array}$ & $\begin{array}{l}73.93 \\
35.20\end{array}$ & $\begin{array}{l}38.29 \\
16.57\end{array}$ & $\begin{array}{l}59.69 \\
2.22\end{array}$ & $\begin{array}{c}165.79 \\
12.87\end{array}$ & $\begin{array}{l}22.05 \\
15.87\end{array}$ & $\begin{array}{l}-0.29 \\
-6.77\end{array}$ & $\begin{array}{l}0.40 \\
0.49\end{array}$ \\
\hline $\begin{array}{l}\text { Mexico } \\
\text { Malaysia }\end{array}$ & $\begin{array}{l}6.25 \\
7.57\end{array}$ & $\begin{array}{l}60.15 \\
52.83\end{array}$ & $\begin{array}{l}73.91 \\
85.34\end{array}$ & $\begin{array}{l}2.39 \\
2.15\end{array}$ & $\begin{array}{l}2.23 \\
0.88\end{array}$ & $\begin{array}{l}3.14 \\
4.28\end{array}$ & $\begin{array}{l}0.48 \\
1.02\end{array}$ & $\begin{array}{l}\text { NA } \\
\text { NA }\end{array}$ & $\begin{array}{c}36.96 \\
130.25\end{array}$ & $\begin{array}{c}34.12 \\
207.07\end{array}$ & $\begin{array}{c}12.37 \\
108.41\end{array}$ & $\begin{array}{l}36.82 \\
53.91\end{array}$ & $\begin{array}{c}0.63 \\
21.33\end{array}$ & $\begin{array}{l}0.63 \\
1.60\end{array}$ & $\begin{array}{l}0.62 \\
0.78\end{array}$ \\
\hline NowZealand & 4.77 & 72.66 & 83.17 & 2.62 & 2.37 & 0.34 & 1.33 & NA & 98.74 & 54.38 & 16.52 & 30.29 & 19.31 & 1.62 & 0.11 \\
\hline $\begin{array}{l}\text { Netherlands } \\
\text { Norway }\end{array}$ & $\begin{array}{l}5.19 \\
6.91\end{array}$ & $\begin{array}{l}55.79 \\
63.79\end{array}$ & $\begin{array}{l}67.75 \\
65.90\end{array}$ & $\begin{array}{l}1.60 \\
2.47\end{array}$ & $\begin{array}{l}1.76 \\
1.97\end{array}$ & $\begin{array}{l}1.01 \\
1.01\end{array}$ & $\begin{array}{l}0.86 \\
1.00\end{array}$ & $\begin{array}{l}N A \\
N A\end{array}$ & $\begin{array}{c}113.14 \\
79.07\end{array}$ & $\begin{array}{l}96.18 \\
30.67\end{array}$ & $\begin{array}{l}72.92 \\
18.51\end{array}$ & $\begin{array}{l}64.23 \\
57.08\end{array}$ & $\begin{array}{c}132.58 \\
29.78\end{array}$ & $\begin{array}{r}-2.25 \\
-1.82\end{array}$ & $\begin{array}{l}0.24 \\
0.66\end{array}$ \\
\hline $\begin{array}{l}\text { Portugal } \\
\text { Singapore }\end{array}$ & $\begin{array}{c}5.63 \\
11.18\end{array}$ & $\begin{array}{l}41.46 \\
43.60\end{array}$ & $\begin{array}{l}80.59 \\
82.27\end{array}$ & $\begin{array}{l}2.58 \\
1.33\end{array}$ & $\begin{array}{l}2.02 \\
0.47\end{array}$ & $\begin{array}{l}3.92 \\
2.30\end{array}$ & $\begin{array}{l}0.75 \\
1.24\end{array}$ & $\begin{array}{l}27.41 \\
63.79\end{array}$ & $\begin{array}{l}89.05 \\
81.66\end{array}$ & $\begin{array}{l}27.44 \\
159.46\end{array}$ & $\begin{array}{l}14.24 \\
76.88\end{array}$ & $\begin{array}{l}42.32 \\
46.79\end{array}$ & $\begin{array}{l}10.40 \\
94.06\end{array}$ & $\begin{array}{c}\text { NA } \\
11.63\end{array}$ & $\begin{array}{c}\mathrm{NA} \\
0.28\end{array}$ \\
\hline Sweden & 5.15 & 68.54 & 46.94 & 1.63 & 1.11 & 0.55 & 0.44 & 21.80 & 125.93 & 84.09 & 48.84 & 52.53 & 39.84 & -7.41 & 1.09 \\
\hline Thalland & 6.30 & 66.77 & 78.43 & 2.31 & 1.64 & 2.38 & -0.35 & NA & 130.67 & 57.43 & 38.43 & 72.10 & 3.86 & 1.22 & 1.18 \\
\hline Turkey & 10.31 & 37.68 & 74.91 & 7.71 & 4.83 & 2.70 & 3.56 & 79.64 & 33.03 & 21.38 & 22.22 & 115.83 & 0.24 & -5.67 & 0.41 \\
\hline $\begin{array}{l}\text { South Africa } \\
\text { United States }\end{array}$ & $\begin{array}{l}7.67 \\
6.35\end{array}$ & $\begin{array}{l}66.79 \\
37.44\end{array}$ & $\begin{array}{l}82.68 \\
63.82\end{array}$ & $\begin{array}{l}3.04 \\
2.18\end{array}$ & $\begin{array}{l}2.91 \\
2.72\end{array}$ & $\begin{array}{l}1.02 \\
3.43\end{array}$ & $\begin{array}{l}1.53 \\
1.43\end{array}$ & $\begin{array}{l}\text { NA } \\
\text { NA }\end{array}$ & $\begin{array}{l}134.17 \\
133.24\end{array}$ & $\begin{array}{l}157.36 \\
109.05\end{array}$ & $\begin{array}{l}22.21 \\
91.32\end{array}$ & $\begin{array}{l}13.95 \\
77.08\end{array}$ & $\begin{array}{c}102.69 \\
86.99\end{array}$ & $\begin{array}{r}-5.45 \\
-2.38\end{array}$ & $\begin{array}{l}0.52 \\
0.28\end{array}$ \\
\hline
\end{tabular}


Gregorio Impavido, Alberto R. Musalem, and Thierry Tressel

Table 4: Pairwise Correlations

\begin{tabular}{|c|c|c|c|c|c|c|c|}
\hline \multirow{2}{*}{ ETA } & ETA & LTA & STFTA & NIM & Profit & OTTA & CTA \\
\hline & 1 & & & & & & \\
\hline LTA & $\begin{array}{r}-0.0161 \\
0.7717\end{array}$ & 1 & & & & $\cdot$ & \\
\hline STFTA & $\begin{array}{r}0.0801 \\
0.1502\end{array}$ & $\begin{array}{r}0.0164 \\
0.7693\end{array}$ & 1 & & & & \\
\hline NIM & $\begin{array}{r}0.4629 \\
0\end{array}$ & $\begin{array}{r}-0.1108 \\
0.0455\end{array}$ & $\begin{array}{r}0.0448 \\
0.4218\end{array}$ & 1 & & & \\
\hline Profit & $\begin{array}{r}0.4304 \\
0\end{array}$ & $\begin{array}{r}-0.0825 \\
0.1386\end{array}$ & $\begin{array}{r}-0.0181 \\
0.7448\end{array}$ & $\begin{array}{r}0.4237 \\
0\end{array}$ & 1 & & \\
\hline OTTA & $\begin{array}{r}0.4622 \\
0\end{array}$ & $\begin{array}{r}-0.2043 \\
0.0002\end{array}$ & $\begin{array}{r}0.0368 \\
0.5092\end{array}$ & $\begin{array}{r}0.6905 \\
0\end{array}$ & $\begin{array}{r}0.1428 \\
0.0101\end{array}$ & 1 & \\
\hline CTA & $\begin{array}{r}-0.0217 \\
0.6976\end{array}$ & $\begin{array}{r}-0.2578 \\
0\end{array}$ & $\begin{array}{r}-0.1733 \\
0.0017\end{array}$ & $\begin{array}{r}-0.0088 \\
0.8744\end{array}$ & $\begin{array}{r}-0.0065 \\
0.9069\end{array}$ & $\begin{array}{r}0.0316 \\
0.5704\end{array}$ & 1 \\
\hline STL & $\begin{array}{r}0.2065 \\
0.0214\end{array}$ & $\begin{array}{r}-0.6058 \\
0\end{array}$ & $\begin{array}{r}0.2039 \\
0.0231\end{array}$ & $\begin{array}{r}0.2517 \\
0.0048\end{array}$ & $\begin{array}{r}0.1798 \\
0.0457\end{array}$ & $\begin{array}{r}0.3336 \\
0.0002\end{array}$ & $\begin{array}{r}0.2593 \\
0.0036\end{array}$ \\
\hline LLTA & $\begin{array}{r}0.14 \\
0.0133\end{array}$ & $\begin{array}{r}0.0795 \\
0.1612\end{array}$ & $\begin{array}{r}0.0554 \\
0.3308\end{array}$ & $\begin{array}{l}0.193 \\
0.0006\end{array}$ & $\begin{array}{r}-0.4666 \\
0\end{array}$ & $\begin{array}{r}0.2647 \\
0\end{array}$ & $\begin{array}{r}0.0095 \\
0.8678\end{array}$ \\
\hline LLLN & $\begin{array}{r}0.1376 \\
0.015\end{array}$ & $\begin{array}{r}-0.0939 \\
0.0979\end{array}$ & $\begin{array}{r}0.0408 \\
0.4744\end{array}$ & $\begin{array}{r}0.2244 \\
0.0001\end{array}$ & $\begin{array}{r}-0.4432 \\
0\end{array}$ & $\begin{array}{r}0.3275 \\
0\end{array}$ & $\begin{array}{r}0.0516 \\
0.3651\end{array}$ \\
\hline oc2 & $\begin{array}{r}-0.3393 \\
0\end{array}$ & $\begin{array}{r}0.1425 \\
0.0171\end{array}$ & $\begin{array}{r}0.1167 \\
0.0515\end{array}$ & $\begin{array}{r}-0.3363 \\
0\end{array}$ & $\begin{array}{r}-0.1954 \\
0.001\end{array}$ & $\begin{array}{r}-0.2887 \\
0\end{array}$ & $\begin{array}{r}-0.1226 \\
0.0407\end{array}$ \\
\hline ec12 & $\begin{array}{r}0.0212 \\
0.7182\end{array}$ & $\begin{array}{r}0.0587 \\
0.3185\end{array}$ & $\begin{array}{r}0.1681 \\
0.0041\end{array}$ & $\begin{array}{r}-0.2161 \\
0.0002\end{array}$ & $\begin{array}{r}0.1188 \\
0.0433\end{array}$ & $\begin{array}{r}-0.247 \\
0\end{array}$ & $\begin{array}{r}-0.0459 \\
0.4363\end{array}$ \\
\hline ec19 & $\begin{array}{r}-0.0116 \\
0.8441\end{array}$ & $\begin{array}{r}-0.0683 \\
0.2462\end{array}$ & $\begin{array}{r}0.0392 \\
0.5067\end{array}$ & $\begin{array}{r}-0.2017 \\
0.0005\end{array}$ & $\begin{array}{r}0.1271 \\
0.0307\end{array}$ & $\begin{array}{r}-0.205 \\
0.0005\end{array}$ & $\begin{array}{r}-0.0315 \\
0.5935\end{array}$ \\
\hline TOR & $\begin{array}{r}-0.0383 \\
0.5154\end{array}$ & $\begin{array}{r}-0.0591 \\
0.3161\end{array}$ & $\begin{array}{r}-0.0606 \\
0.3048\end{array}$ & $\begin{array}{r}0.0028 \\
0.962\end{array}$ & $\begin{array}{r}0.1148 \\
0.0513\end{array}$ & $\begin{array}{r}-0.0373 \\
0.5272\end{array}$ & $\begin{array}{r}-0.0961 \\
0.1032\end{array}$ \\
\hline $\operatorname{LogCSfa}, \%$ GDP & $\begin{array}{r}-0.2026 \\
0.0032\end{array}$ & $\begin{array}{r}0.2006 \\
0.0035\end{array}$ & $\begin{array}{r}0.0259 \\
0.7095\end{array}$ & $\begin{array}{r}-0.5857 \\
0\end{array}$ & $\begin{array}{r}-0.2577 \\
0.0002\end{array}$ & $\begin{array}{r}-0.434 \\
0\end{array}$ & $\begin{array}{r}-0.253 \\
0.0002\end{array}$ \\
\hline \multirow[t]{2}{*}{ Csfa,\%GDP } & $\begin{array}{r}0.0204 \\
0.7691\end{array}$ & $\begin{array}{r}0.1166 \\
0.092\end{array}$ & $\begin{array}{r}0.1019 \\
0.1413\end{array}$ & $\begin{array}{r}-0.2648 \\
0.0001\end{array}$ & $\begin{array}{r}0.0233 \\
0.7375\end{array}$ & $\begin{array}{r}-0.187 \\
0.0066\end{array}$ & $\begin{array}{r}-0.1611 \\
0.0195\end{array}$ \\
\hline & STL & LLTA & LLLLN & $\bullet c 2$ & $\theta c 12$ & ects & TOR \\
\hline STL & 1 & & & & & & \\
\hline LLTA & $\begin{array}{r}-0.046 \\
0.6123\end{array}$ & 1 & & & & & \\
\hline LLLN & $\begin{array}{r}0.0419 \\
0.6442\end{array}$ & $\begin{array}{r}0.9613 \\
0\end{array}$ & 1 & & & & \\
\hline oc2 & $\begin{array}{r}-0.1445 \\
0.1413\end{array}$ & $\begin{array}{r}-0.024 \\
0.6949\end{array}$ & $\begin{array}{r}-0.066 \\
0.2809\end{array}$ & 1 & & & \\
\hline ec12 & $\begin{array}{r}0.0761 \\
0.4297\end{array}$ & $\begin{array}{l}-0.19 \\
0.0014\end{array}$ & $\begin{array}{r}-0.1967 \\
0.0009\end{array}$ & $\begin{array}{r}0.3627 \\
0\end{array}$ & 1 & & \\
\hline ect9 & $\begin{array}{r}0.2208 \\
0.021\end{array}$ & $\begin{array}{r}-0.1593 \\
0.0076\end{array}$ & $\begin{array}{r}-0.1462 \\
0.0144\end{array}$ & $\begin{array}{r}0.3224 \\
0\end{array}$ & $\begin{array}{r}0.7544 \\
0\end{array}$ & 1 & \\
\hline TOR & $\begin{array}{r}0.1792 \\
0.0622\end{array}$ & $\begin{array}{r}-0.1032 \\
0.0849\end{array}$ & $\begin{array}{r}-0.0878 \\
0.1429\end{array}$ & $\begin{array}{r}0.0203 \\
0.7352\end{array}$ & $\begin{array}{r}-0.0204 \\
0.727\end{array}$ & $\begin{array}{r}0.4393 \\
0\end{array}$ & 1 \\
\hline LogCSfa,\%GDP & $\begin{array}{r}-0.4895 \\
0\end{array}$ & $\begin{array}{r}-0.1504 \\
0.0327\end{array}$ & $\begin{array}{r}-0.2295 \\
0.001\end{array}$ & $\begin{array}{r}0.3929 \\
0\end{array}$ & $\begin{array}{r}0.571 \\
0\end{array}$ & $\begin{array}{r}0.3587 \\
o\end{array}$ & $\begin{array}{r}-0.2162 \\
0.0017\end{array}$ \\
\hline Csfa,\%GDP & $\begin{array}{r}-0.2067 \\
0.0592\end{array}$ & $\begin{array}{r}-0.1795 \\
0.0106\end{array}$ & $\begin{array}{r}-0.2355 \\
0.0007\end{array}$ & $\begin{array}{r}0.2947 \\
0\end{array}$ & $\begin{array}{r}0.7248 \\
0\end{array}$ & $\begin{array}{r}0.5148 \\
0\end{array}$ & $\begin{array}{r}-0.1285 \\
0.0644\end{array}$ \\
\hline
\end{tabular}


Figure 1: Maturity of Loans and Contractual Savings

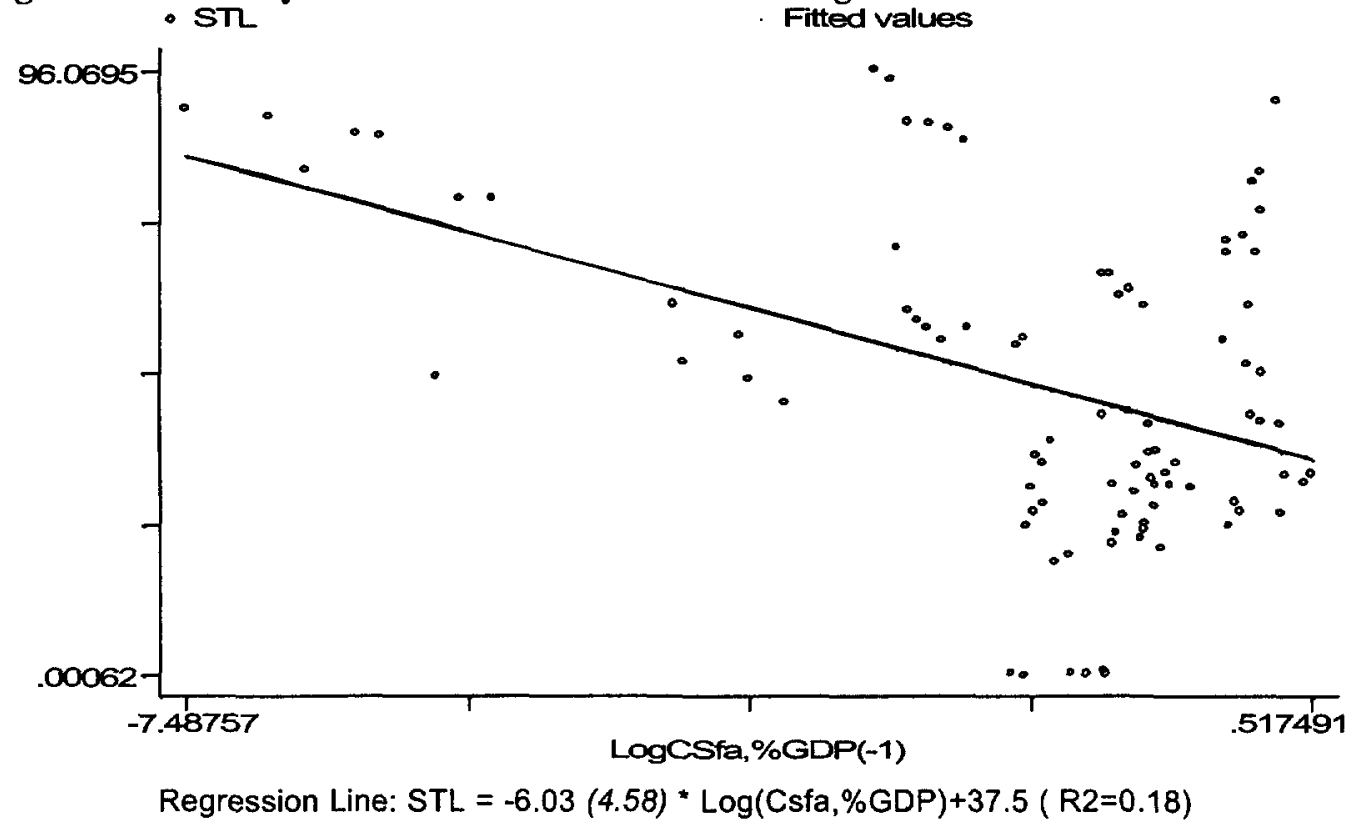

Figure 2: Net Interest Margin and Contractual Savings

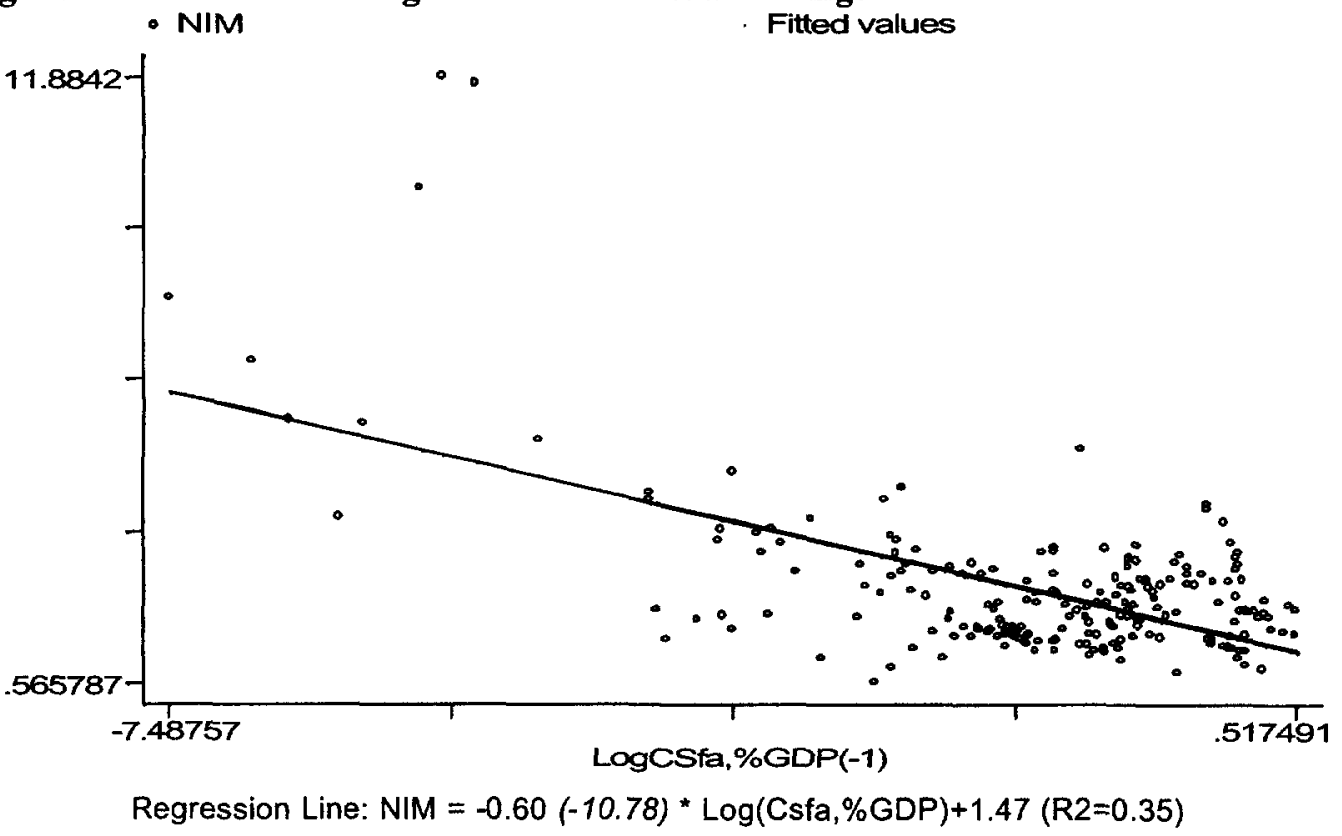


Gregorio Impavido, Alberto R. Musalem, and Thierry Tressel

Figure 3: Credit Risk and Contractual Savings

- LTA

- Fitted values

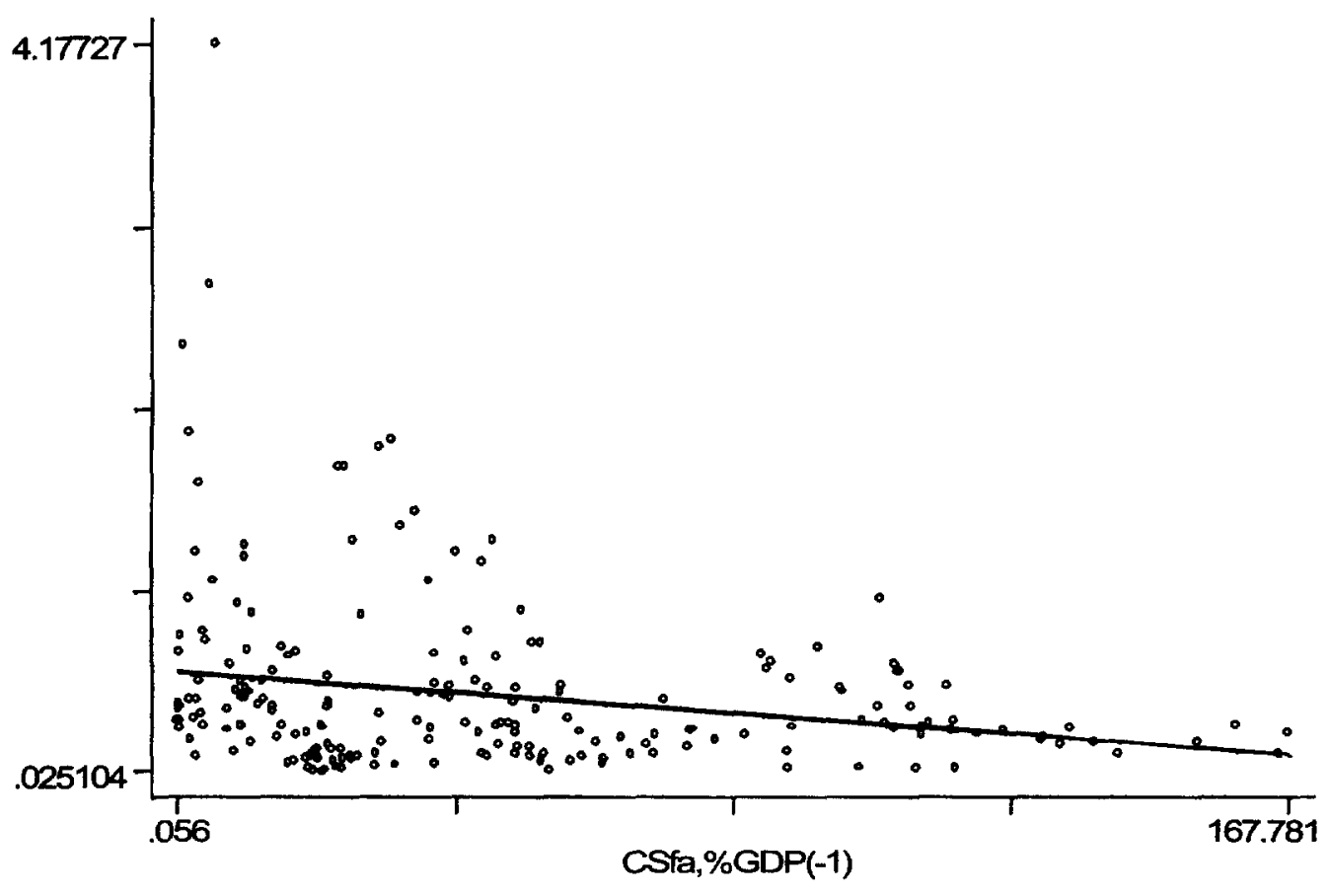

Regression Line: $\operatorname{LLTA}=-2.8 \mathrm{E}-3(-3.23){ }^{*} \mathrm{Csfa}, \% \mathrm{GDP}+0.6(\mathrm{R} 2=0.043)$ 


\section{Table 5 : Contractual Savings Institutions and Bank Net Interest Margins \\ Pooled and Panel Estimates}

\begin{tabular}{|c|c|c|c|c|}
\hline \multirow{3}{*}{$\begin{array}{l}\text { Dependent Variable: } \\
\text { Explanatory Variables: } \\
\text { CS variable }\end{array}$} & \multicolumn{4}{|c|}{ Net Interest Margin } \\
\hline & \multicolumn{2}{|c|}{ OLS } & \multicolumn{2}{|c|}{ Fixed Effects } \\
\hline & dated t-1 & $\mathbf{N}$ & dated $t-1$ & $\mathbf{N}$ \\
\hline \multicolumn{5}{|l|}{ Banks' Characteristics : } \\
\hline Capitalization (ETA) & $0.112^{\star * \star}$ & $0.106^{* * *}$ & $0.15^{\star \star \star}$ & $0.153^{\text {*** }}$ \\
\hline Structure of Assets ( LTA) & $\begin{array}{l}0.031^{\star * *} \\
13.53\end{array}$ & $\begin{array}{c}0.0307^{* * *} \\
12.75\end{array}$ & $\begin{array}{c}0.038^{* * *} \\
10.69\end{array}$ & $0.039^{* \cdots *}$ \\
\hline Sources of Funds (STFTA) & $0.008^{\star \star \star}$ & $0.007^{* * *}$ & $0.005^{*}$ & $0.006 *$ \\
\hline Non Earnings Assets (CTA) & $\begin{array}{c}3.33 \\
-0.007\end{array}$ & $\begin{array}{c}3.02 \\
-0.014\end{array}$ & $\begin{array}{c}1.69 \\
0.027^{\star \star \star \star}\end{array}$ & $\begin{array}{l}1.91 \\
0.012\end{array}$ \\
\hline Overhead (OTTA) & $\begin{array}{c}-0.53 \\
0.377^{\star \star \star} \\
9.01\end{array}$ & $\begin{array}{c}-1.72 \\
0.388^{\star \star \star} \\
8.50\end{array}$ & $\begin{array}{c}2.95 \\
0.533^{\star \star \star} \\
8.77\end{array}$ & $\begin{array}{c}0.60 \\
0.526^{* * *} \\
8.91\end{array}$ \\
\hline \multicolumn{5}{|l|}{ Macroeconomic Factors : } \\
\hline Inflation & $0.038^{* * *}$ & $0.043^{\star \star \star}$ & $-0.028^{* * *}$ & $-0.032 * * *$ \\
\hline GDP growth & $\begin{array}{c}5.46 \\
0.035 * *\end{array}$ & $\begin{array}{c}6.55 \\
0.048^{* \star \star *}\end{array}$ & $\begin{array}{l}-2.82 \\
-0.016\end{array}$ & $-0.021 \cdots *$ \\
\hline & 2.33 & 3.61 & -1.55 & -1.85 \\
\hline Log (GDP/Capita) & $\begin{array}{l}-0.03 \\
-0.47\end{array}$ & $\begin{array}{l}-0.05 \\
-0.72\end{array}$ & $\begin{array}{l}-0.12 \\
-0.54\end{array}$ & $\begin{array}{l}-0.09 \\
.0 .42\end{array}$ \\
\hline Government Budget Balance (\% GDP) & $\begin{array}{l}-0.03^{\star \star \star} \\
-3.71\end{array}$ & $\begin{array}{l}-0.031^{\star \star \star} \\
-3.88\end{array}$ & $\begin{array}{c}-0.016^{\star} \\
-1.63\end{array}$ & $\begin{array}{c}-0.021 \\
-2.17\end{array}$ \\
\hline Financial System Development : & & & & \\
\hline Credit to Private Sector & $\begin{array}{l}-0.0010 \\
-1.00\end{array}$ & $\begin{array}{c}-0.0007 \\
-0.68\end{array}$ & $\begin{array}{l}-0.005^{\star \star} \\
-2.18\end{array}$ & $\begin{array}{l}-0.008^{* * *} \\
-2.83\end{array}$ \\
\hline Stock Market Capitalization & $\begin{array}{l}-0.0008 \\
-0.57\end{array}$ & $\begin{array}{l}-0.0016 \\
-1.12\end{array}$ & $\begin{array}{c}0.0008 \\
0.55\end{array}$ & $\begin{array}{c}0.0010 \\
0.72\end{array}$ \\
\hline Stock Market Activity & $\begin{array}{c}0.0023 \\
1.28\end{array}$ & $\begin{array}{c}0.0030 \\
1.64\end{array}$ & $\begin{array}{c}0.0037^{* * * *} \\
2.69\end{array}$ & $\begin{array}{c}0.0034^{* * *} \\
2.57\end{array}$ \\
\hline $\begin{array}{l}\text { Stock Market Liquidity } \\
\text { (Turnover Ratio) }\end{array}$ & $\begin{array}{l}-0.0026 * * \\
-2.16\end{array}$ & $\begin{array}{c}-0.0032^{* * *} \\
-2.64\end{array}$ & $\begin{array}{c}-0.0029 * * * \\
-3.39\end{array}$ & $\begin{array}{c}-0.0027^{* * *} \\
-3.01\end{array}$ \\
\hline Contractual Savings Development & $-0.171 * \star \star *$ & $-0.17 * * *$ & 0.061 & 0.189 \\
\hline ( Log of financial assets, \% GDP) & -4.26 & -4.27 & 0.47 & 1.39 \\
\hline Year Dummies & Yes & Yes & Yes & Yes \\
\hline Wald Test & $1140.75(20)$ & $1162(20)$ & $3660.1(48)$ & $3865(48)$ \\
\hline $\mathrm{Nb}$ of Observations & 156 & 153 & 156 & 153 \\
\hline $\begin{array}{l}\mathrm{Nb} \text { of Years } \\
\mathrm{Nb} \text { of Countries }\end{array}$ & $\begin{array}{c}7 \\
30\end{array}$ & $\begin{array}{c}7 \\
30\end{array}$ & $\begin{array}{c}7 \\
30\end{array}$ & $\begin{array}{c}7 \\
30\end{array}$ \\
\hline
\end{tabular}

Method of estimation:

GLS, with heteroscedastic error structure and no aulocorrolation within panel; no cross-sectional correlation.

Instruments dated $\mathrm{t}-1$ for contractual savings variable:

dependent variable, real GDP per capita growth, rate of change of M2/GDP, rate of change of real effective exchange rate,

volatility of inflation, volatility of interest rate, openness, share of the population over 64 , bank credit, market capitalization and liquidity 
Gregorio Impavido, Alberto R. Musalem, and Thierry Tressel

\section{Table 6 : Contractual Savings Institutions and Bank Profitability \\ Pooled and Panel Estimates}

\begin{tabular}{|c|c|c|c|c|}
\hline \multirow{2}{*}{$\begin{array}{l}\text { Dependent Variable : } \\
\text { Explanatory Variables : } \\
\text { CS variable }\end{array}$} & \multicolumn{4}{|c|}{ Profitability (Profit before Tax / Total Assets) } \\
\hline & \multicolumn{2}{|c|}{ OLS } & \multicolumn{2}{|c|}{ Fixed Efrects } \\
\hline \multicolumn{5}{|l|}{ Banks' Characteristics : } \\
\hline Capitalization (ETA) & $\begin{array}{c}0.126^{\text {\#* }} \\
6.06\end{array}$ & $\begin{array}{l}0.127^{* * *} \\
5.96\end{array}$ & $\begin{array}{l}0.281^{* * *} \\
10.19\end{array}$ & $\begin{array}{l}0.289^{* * *} \\
10.11\end{array}$ \\
\hline Structure of Assets ( LTA) & $\begin{array}{l}0.021^{* \star *} \\
7.11\end{array}$ & $\begin{array}{l}0.0205 \text { *** } \\
6.94\end{array}$ & $\begin{array}{c}-0.013^{* *} \\
-2.41\end{array}$ & $\begin{array}{l}-0.012^{* *} \\
-2.10\end{array}$ \\
\hline Sources of Funds (STFTA) & $\begin{array}{c}0.016^{* * *} \\
5.65\end{array}$ & $\begin{array}{c}0.017^{* * *} \\
5.54\end{array}$ & $\begin{array}{c}0.0048 \\
0.86\end{array}$ & $\begin{array}{c}0.0056 \\
0.93\end{array}$ \\
\hline Non Earnings Assets (CTA) & $0.022^{\star \star \star}$ & $\begin{array}{l}0.024^{* * *} \\
2.88\end{array}$ & $0.012^{* * *}$ & -0.006 \\
\hline Overhead (OTTA) & $\begin{array}{c}0.033 \\
0.58\end{array}$ & $\begin{array}{c}0.035 \\
0.60\end{array}$ & $\begin{array}{l}-0.219^{\star * \star *} \\
-2.59\end{array}$ & $\begin{array}{c}-0.246 * \star \\
-2.93\end{array}$ \\
\hline Macroeconomic Factors : & & & & \\
\hline Inflation & $\begin{array}{c}0.056^{\star \star \star} \\
7.57\end{array}$ & $\begin{array}{l}0.056^{\star * \star} \\
7.51\end{array}$ & $\begin{array}{c}0.0195 \\
1.42\end{array}$ & $\begin{array}{l}0.033^{\star \star} \\
2.05\end{array}$ \\
\hline GDP growth & $\begin{array}{c}0.066^{\star * \star} \\
3.924\end{array}$ & $\begin{array}{c}0.065^{* * *} \\
3.89\end{array}$ & $\begin{array}{l}0.038^{* * *} \\
2.596\end{array}$ & $\begin{array}{l}0.056^{* * \star} \\
3.218\end{array}$ \\
\hline Log (GDP/Capita) & $\begin{array}{l}0.27^{\star \star \star} \\
2.663\end{array}$ & $\begin{array}{l}0.308^{* * *} \\
2.894\end{array}$ & $\begin{array}{c}1.18^{* * *} \\
3.319\end{array}$ & $\begin{array}{c}1.12^{k * \star} \\
3.202\end{array}$ \\
\hline Government Budget Balance (\% GDP) & $\begin{array}{l}-0.013 \\
-1.351\end{array}$ & $\begin{array}{l}-0.015 \\
-1.525\end{array}$ & $\begin{array}{l}-0.008 \\
-0.586\end{array}$ & $\begin{array}{l}-0.014 \\
-0.967\end{array}$ \\
\hline Financial System Development : & & & & \\
\hline Credit to Private Sector & $\begin{array}{c}0.0036^{\star \star \star} \\
3.39\end{array}$ & $\begin{array}{c}0.0037^{* * *} \\
3.40\end{array}$ & $\begin{array}{c}-0.0139^{\star \star \star} \\
-3.88\end{array}$ & $\begin{array}{c}-0.0138 * * * \\
-3.09\end{array}$ \\
\hline Stock Market Capitalization & $\begin{array}{c}-0.00076 \\
-0.468\end{array}$ & $\underset{-0.00024}{-0.144}$ & $\begin{array}{c}-0.00066 \\
-0.371\end{array}$ & $\begin{array}{c}-0.00027 \\
-0.138\end{array}$ \\
\hline Stock Market Activity & $\begin{array}{c}0.0029 \\
1.47\end{array}$ & $\begin{array}{c}0.0025 \\
1.28\end{array}$ & $\begin{array}{c}0.0020 \\
1.19\end{array}$ & $\begin{array}{c}0.0013 \\
0.74\end{array}$ \\
\hline $\begin{array}{l}\text { Stock Market Liquidity } \\
\text { (Turnover Ratio) }\end{array}$ & $\begin{array}{c}-0.002^{* * *} \\
-2.61\end{array}$ & $\begin{array}{c}-0.0019 \text { ** } \\
-2.26\end{array}$ & $\begin{array}{c}-0.0011 \\
-1.19\end{array}$ & $\begin{array}{c}-0.001 \\
-0.64\end{array}$ \\
\hline $\begin{array}{l}\text { Contractual Savings Development } \\
\text { ( Log of financial assets, \% GDP) }\end{array}$ & $\begin{array}{l}0.313 \\
0.096\end{array}$ & $\begin{array}{l}-0.239 \\
-0.478\end{array}$ & $\begin{array}{c}0.31 * \\
1.87\end{array}$ & $\begin{array}{c}0.316 \text { * } \\
1.61\end{array}$ \\
\hline Year Dummies & Yes & Yes & Yes & Yes \\
\hline Wald Test & $418.9(20)$ & $405.46(20)$ & $1202(48)$ & $1117.85(48)$ \\
\hline $\mathrm{Nb}$ of Observations & 156 & 153 & 156 & 153 \\
\hline $\begin{array}{l}\mathrm{Nb} \text { of Years Included } \\
\mathrm{Nb} \text { of Countries }\end{array}$ & $\begin{array}{c}7 \\
30\end{array}$ & $\begin{array}{c}7 \\
30\end{array}$ & $\begin{array}{c}7 \\
30\end{array}$ & $\begin{array}{c}7 \\
30\end{array}$ \\
\hline
\end{tabular}

Method of estimation:

GLS, with heteroscedastic error structure and no autocorralation within penel; no cross-sectional comalation.

Instruments dated $t-1$ for contractual savings variable:

contractual savings variable, real GDP per capita growth, rate of change of M2/GDP, rate of change of real effective exchange rate.

volatility of inflation, volatility of interest rate, openness, share of the population over 64 , bank credit, market capitalization and liquidity 
Gregorio Impavido, Alberto R. Musalem, and Thierry Tressel

\section{Table 7 : Contractual Savings Institutions and Bank Loan Maturity}

Pooled and Panel Estimates

\begin{tabular}{|c|c|c|c|c|}
\hline \multirow{3}{*}{$\begin{array}{l}\text { Dependent Variable: } \\
\text { Explanatory Variables: } \\
\text { CS variable }\end{array}$} & \multicolumn{4}{|c|}{ Loan Maturity (Short-term Loans / Total Loans) } \\
\hline & \multicolumn{2}{|c|}{ OLS } & \multicolumn{2}{|c|}{ Fixed Effects } \\
\hline & dated $t-1$ & $\mathbf{N}$ & dated $\leqslant 1$ & IV \\
\hline \multicolumn{5}{|l|}{ Banks' Characteristics : } \\
\hline \multirow[t]{2}{*}{ Capitalization (ETA) } & -0.727 & -0.822 & 0.776 & $1.414 *$ \\
\hline & -0.66 & -0.71 & 0.99 & 1.62 \\
\hline \multirow[t]{2}{*}{ Structure of Assets ( LTA) } & -0.026 & 0.169 & $-1.024^{\star * *}$ & $-1.305 *$ \\
\hline & -0.05 & 0.32 & -2.74 & -3.23 \\
\hline \multirow[t]{2}{*}{ Sources of Funds (STFTA) } & $0.577 * \star$ & 0.496 & 0.259 & $0.503 *$ \\
\hline & 1.82 & 1.33 & 0.93 & 1.70 \\
\hline \multirow[t]{2}{*}{ Non Eamings Assets (CTA) } & -0.046 & -0.570 & $-0.725^{\star \star}$ & 0.665 \\
\hline & -0.07 & -0.66 & -2.33 & 1.05 \\
\hline \multirow[t]{2}{*}{ Overhead (OTTA) } & -3.61 & -2.38 & $-11.19 * * *$ & $-11.81 \cdots$ \\
\hline & -0.85 & -0.55 & -3.07 & -2.86 \\
\hline \multicolumn{5}{|l|}{ Macroeconomic Factors : } \\
\hline \multirow[t]{2}{*}{ Inflation } & -0.543 & $-1.059 * *$ & $-1.96^{\star \star \star}$ & $-1.82^{\star \star \star}$ \\
\hline & -1.04 & -1.82 & -4.81 & -3.34 \\
\hline \multirow[t]{2}{*}{ GDP growth } & -0.334 & -0.707 & $-1.48^{\star \star \star *}$ & $-1.35 * *$ \\
\hline & -0.42 & -0.83 & -2.84 & -1.93 \\
\hline \multirow[t]{2}{*}{$\log ($ GDP/Capita) } & -10.34 & $-30.96^{* *}$ & $-32.59 * \star *$ & $-30.28 * *$ \\
\hline & -0.92 & -1.86 & -2.59 & -2.29 \\
\hline \multirow[t]{2}{*}{ Government Budget Balance ( $\%$ GDP) } & 0.727 & 1.237 & $1.738^{* * *}$ & $2.108^{\star \star \star}$ \\
\hline & 1.04 & 1.52 & 3.04 & 3.41 \\
\hline \multicolumn{5}{|l|}{ Financial System Development : } \\
\hline \multirow[t]{2}{*}{ Credit to Private Sector } & -0.033 & -0.003 & 0.208 & 0.258 \\
\hline & -0.45 & -0.03 & 1.46 & 1.23 \\
\hline \multirow[t]{2}{*}{ Stock Market Capitalization } & -0.100 & -0.217 & -0.068 & -0.090 \\
\hline & -0.82 & -1.49 & -0.64 & -0.82 \\
\hline \multirow[t]{2}{*}{ Stock Market Activity } & $0.544^{\star * \star}$ & $0.676^{\star \star \star \hbar}$ & $0.315^{\star \star \star}$ & $0.311^{* * *}$ \\
\hline & 347 & 3.97 & 2.82 & 270 \\
\hline Stock Market Liquidity & -0.081 & -0.106 & $-0.104^{* * *}$ & $-0.135 * *$ \\
\hline (Turnover Ratio) & -0.88 & -1.08 & -2.87 & -3.39 \\
\hline Contractual Savings Development & $-11.98 * \star$ & $-10.86 * *$ & -8.123 & $-11.9 * \star$ \\
\hline ( Log of financial assets, \% GDP) & -2.94 & -2.19 & -1.48 & -1.84 \\
\hline Year Dummies & Yes & Yes & Yes & Yes \\
\hline Wald Test & $193.73(19)$ & $165(23)$ & $4660.5(32)$ & $2329(33)$ \\
\hline Log Likelihood & -237.36 & -235.13 & -154.5 & -153.51 \\
\hline Nb of Observations & 67 & 65 & 67 & 65 \\
\hline $\mathrm{Nb}$ of Years & 6 & 6 & 6 & 6 \\
\hline $\mathrm{Nb}$ of Countries & 14 & 14 & 14 & 14 \\
\hline
\end{tabular}

Method of estimation

GLS, with heteroscedastic error structure and no autocorrelation within panel; no cross-sectional carrelation.

Instruments dated t-1 for contractual savings variable:

dependent variable, real GDP per capita growth, rate of change of MVIGDP, rate of change of real effective exchenge rate,

volatility of inflation, volatility of interest rate, openness, share of the population over 64 , bank credit, market capitalization and liquidity 
Gregorio Impavido, Alberto R. Musalem, and Thierry Tressel

\section{Table 8 : Contractual Savings Institutions and Bank Credit Risk \\ Pooled and Panel Estimates}

\begin{tabular}{|c|c|c|c|c|}
\hline \multirow{2}{*}{$\begin{array}{l}\text { Dependent Variable : } \\
\text { Explanatory Variables: } \\
\text { CS variable }\end{array}$} & \multicolumn{4}{|c|}{ Loan Loss Provisions / Total Assets } \\
\hline & \multicolumn{2}{|c|}{ OLS } & \multicolumn{2}{|c|}{ Fixed Effects } \\
\hline \multicolumn{5}{|l|}{ Banks' Characteristics : } \\
\hline Capitalization (ETA) & $\begin{array}{l}0.048^{\star \star \star \star} \\
3.73\end{array}$ & $\begin{array}{l}0.056^{* * *} \\
4.40\end{array}$ & $-0.063^{-4.31}$ & $\begin{array}{c}-0.064^{* * *} \\
-4.48\end{array}$ \\
\hline Structure of Assets ( LTA ) & $\begin{array}{c}0.0031^{\star \star} \\
2.02\end{array}$ & $\begin{array}{c}0.0028 \text { ** } \\
1.85\end{array}$ & $\begin{array}{l}0.012^{\star * *} \\
6.28\end{array}$ & $\begin{array}{l}0.010^{* * *} \\
5.00\end{array}$ \\
\hline Sources of Funds (STFTA) & $\begin{array}{c}-0.002^{\star} \\
-1.66\end{array}$ & $\begin{array}{l}-0.002 \\
-1.34\end{array}$ & $\begin{array}{c}-0.004^{*} \\
-1.77\end{array}$ & $\begin{array}{l}-0.005^{*} \\
-1.95\end{array}$ \\
\hline Non Earnings Assets (CTA) & $\begin{array}{c}0.0039 \\
0.82\end{array}$ & $\begin{array}{c}0.0038 \\
0.93\end{array}$ & $\begin{array}{l}0.004^{\star *} \\
1.85\end{array}$ & $\begin{array}{c}0.011 \\
1.13\end{array}$ \\
\hline Overhead (OTTA) & $\begin{array}{l}0.044^{* * *} \\
2.44\end{array}$ & $\begin{array}{l}0.027 \\
1.42\end{array}$ & $\begin{array}{l}0.16^{\star \star \star \star} \\
4.25\end{array}$ & $\begin{array}{c}0.17^{* * *} \\
4.63\end{array}$ \\
\hline Macroeconomic Factors : & & & & \\
\hline Inflation & $\begin{array}{l}-0.028^{* * *} \\
-6.60\end{array}$ & $\begin{array}{c}-0.027 \text { *** } \\
-6.38\end{array}$ & $\begin{array}{l}-0.025^{* * *} \\
-3.72\end{array}$ & $\begin{array}{l}-0.025 * \star * \pi \\
3.54\end{array}$ \\
\hline GDP growth & $\begin{array}{l}-0.059^{* \star \star} \\
-6.22\end{array}$ & $\begin{array}{c}-0.055^{\star \star \star} \\
-6.23\end{array}$ & $\begin{array}{c}-0.037^{* * *} \\
-4.87\end{array}$ & $\begin{array}{l}-0.033^{\star \star \star} \\
-4.29\end{array}$ \\
\hline Log (GDP/Capita) & $\begin{array}{l}-0.167^{* * *} \\
-3.01\end{array}$ & $-0.175^{* * *}$ & 0.105 & 0.040 \\
\hline Government Budget Balance (\% GDP) & $-0.026^{* * *}$ & $-0.028^{-0.14 * *}$ & $\begin{array}{c}-0.014^{\star *} \\
-2.06\end{array}$ & -0.009 \\
\hline Financial System Development : & & & & \\
\hline Credit to Private Sector & $\begin{array}{l}-0.0017^{* \star *} \\
-3.02\end{array}$ & $\begin{array}{l}-0.0016^{\star \star \star} \\
-2.89\end{array}$ & $\begin{array}{l}0.016^{* \star *} \\
8.55\end{array}$ & $\begin{array}{l}0.018^{* * *} \\
8.98\end{array}$ \\
\hline Stock Market Capitalization & $\begin{array}{l}0.0009 \\
1.042\end{array}$ & $\begin{array}{c}0.0003 \\
0.364\end{array}$ & $\begin{array}{l}-0.002 * * \\
-2.159\end{array}$ & $\begin{array}{l}-0.0023 * * * \\
-2.796\end{array}$ \\
\hline Stock Market Activity & $\begin{array}{c}0.0008 \\
0.86\end{array}$ & $\begin{array}{c}0.0013 \\
1.36\end{array}$ & $\begin{array}{c}0.0025^{* * *} \\
3.04\end{array}$ & $\begin{array}{c}0.0031 \\
4.02\end{array}$ \\
\hline $\begin{array}{l}\text { Stock Market Liquidity } \\
\text { (Turnover Ratio) }\end{array}$ & $\begin{array}{c}0.0001 \\
0.12\end{array}$ & $\begin{array}{c}-0.0001 \\
-0.183\end{array}$ & $\underset{-1.713}{-0.0009 *}$ & $\begin{array}{l}-0.001^{* *} \\
-208\end{array}$ \\
\hline $\begin{array}{l}\text { Contractual Savings Development } \\
\text { ( Financial assets, \% GDP) }\end{array}$ & $\begin{array}{c}-0.0017 \\
-2.86\end{array}$ & $\begin{array}{c}-0.0013 \\
-2.30\end{array}$ & $-0.0042 *$ & $-0.0064 *$ \\
\hline Year Dummies & Yes & Yes & Yes & Yes \\
\hline Wald Test & $290.5(20)$ & $289.3(20)$ & $1412(48)$ & $1841.3(48)$ \\
\hline $\mathrm{Nb}$ of Observations & 153 & 151 & 153 & 151 \\
\hline $\begin{array}{l}\mathrm{Nb} \text { of Years Included } \\
\mathrm{Nb} \text { of Countries }\end{array}$ & $\begin{array}{c}7 \\
30\end{array}$ & $\begin{array}{l}7 \\
30\end{array}$ & $\begin{array}{c}7 \\
30\end{array}$ & $\begin{array}{c}7 \\
30\end{array}$ \\
\hline
\end{tabular}

Method of estimetion:

GLS, with heteroscedastic error structure and no autocorrelation within panel; no cross-sectional correlation.

Instruments dated $t-1$ for contractual savings variable:

contractual savings variable, real GDP per capita growth, rate of change of M2/GDP, rate of change of real effective exchange rate,

volatility of inflation, volatility of interest rate, openness, share of the population over 64 , bank credit, market capitalization and liquidity 


\section{Table 9 : Contractual Savings Institutions and Bank Credit Risk \\ Pooled and Panel Estimates}

\begin{tabular}{|c|c|c|c|c|}
\hline \multirow{2}{*}{$\begin{array}{l}\text { Dependent Variable : } \\
\text { Explanatory Variables : } \\
\text { CS variable }\end{array}$} & \multicolumn{4}{|c|}{ Loan Loss Provisions / Loans } \\
\hline & \multicolumn{2}{|c|}{ dated $t-1{ }^{O L S}$} & \multicolumn{2}{|c|}{ Fixed Effects } \\
\hline \multicolumn{5}{|l|}{ Banks' Characteristics : } \\
\hline Capitalization (ETA) & $\begin{array}{l}0.07^{\star \star *} \\
3.31\end{array}$ & $\begin{array}{l}0.08^{\star \star *} \\
3.80\end{array}$ & $\begin{array}{l}-0.12^{\star \star *} \\
-4.95\end{array}$ & $\begin{array}{c}-0.13^{\star \star \star} \\
-5.41\end{array}$ \\
\hline Structure of Assets ( LTA) & $\begin{array}{c}-0.022^{\star \star *} \\
-7.25\end{array}$ & $\begin{array}{c}-0.02^{* * *} \\
-7.47\end{array}$ & $\begin{array}{l}-0.022^{* \star *} \\
-6.91\end{array}$ & $\begin{array}{l}-0.02^{\star \star \star} \\
-7.55\end{array}$ \\
\hline Sources of Funds (STFTA) & $\begin{array}{c}-0.01 * * * \\
-2.99\end{array}$ & $\begin{array}{c}-0.01^{\star \star \star} \\
-2.68\end{array}$ & $\begin{array}{c}-0.004 \\
-0.82\end{array}$ & $\begin{array}{l}-0.003 \\
-0.75\end{array}$ \\
\hline Non Earnings Assets (CTA) & $\begin{array}{c}0.005 \\
0.43\end{array}$ & $\begin{array}{c}0.003 \\
0.33\end{array}$ & $\begin{array}{c}0.006 \\
0.73\end{array}$ & $\begin{array}{c}0.014 \\
0.70\end{array}$ \\
\hline Overhead (OTTA) & $\begin{array}{l}0.26 \text { **** } \\
9.06\end{array}$ & $\begin{array}{l}0.26^{* * *} \\
9.83\end{array}$ & $\begin{array}{c}0.55^{* \star *} \\
8,37\end{array}$ & $\begin{array}{l}0.53^{* * *} \\
8.42\end{array}$ \\
\hline Macroeconomic Factors: & & & & \\
\hline Inflation & $\begin{array}{l}-0.06^{\star \star * *} \\
-7.77\end{array}$ & $\begin{array}{l}-0.06^{* * *} \\
-7.75\end{array}$ & $\begin{array}{l}-0.05^{* * *} \\
-3.76\end{array}$ & $\begin{array}{c}-0.04^{* * *} \\
-3.56\end{array}$ \\
\hline GDP growth & $\begin{array}{c}-0.11 * * * \\
-6.38\end{array}$ & $\begin{array}{c}-0.10 * * * \\
-6.31\end{array}$ & $\begin{array}{c}-0.07^{\star \star \star} \\
-5.41\end{array}$ & $\begin{array}{l}-0.07^{* * *} \\
-5.54\end{array}$ \\
\hline $\log$ (GDP/Capita) & $\begin{array}{l}-0.27^{\star \star \star *} \\
-2.86\end{array}$ & $\begin{array}{c}-0.30^{* * *} \\
-3.16\end{array}$ & $\begin{array}{c}0.50 \text { ** } \\
1.99\end{array}$ & $\begin{array}{c}0.56 \text { ** } \\
2.38\end{array}$ \\
\hline Government Budget Balance ( $\%$ GDP) & $\begin{array}{c}-0.04 * * * \\
-3.959\end{array}$ & $\begin{array}{c}-0.03 * * * \\
-3.912\end{array}$ & $\begin{array}{l}-0.01 \\
-1.084\end{array}$ & $\begin{array}{l}-0.01 \\
-0.824\end{array}$ \\
\hline Financial System Development : & & & & \\
\hline Credit to Private Sector & $\begin{array}{l}-0.004^{\star \star \star \star} \\
-4.65\end{array}$ & $\begin{array}{l}-0.005^{* * *} \\
-4.53\end{array}$ & $\begin{array}{l}0.028 \text { ** } \\
9.18\end{array}$ & $\begin{array}{c}0.029 * * * \\
9.66\end{array}$ \\
\hline Stock Market Capitalization & $\begin{array}{c}0.003^{*} \\
1.85\end{array}$ & $\begin{array}{c}0.002 \\
1.14\end{array}$ & $\begin{array}{l}-0.0005 \\
-0.34\end{array}$ & $\begin{array}{c}-0.0009 \\
-0.61\end{array}$ \\
\hline Stock Market Activity & $\begin{array}{c}0.0006 \\
0.36\end{array}$ & $\begin{array}{c}0.0014 \\
0.89\end{array}$ & $\begin{array}{c}0.001 \\
0.96\end{array}$ & $\begin{array}{l}0.003 \\
2.08\end{array}$ \\
\hline $\begin{array}{l}\text { Stock Market Liquidity } \\
\text { (Tumover Ratio) }\end{array}$ & $\begin{array}{c}0.0014 \\
1.16\end{array}$ & $\begin{array}{c}0.0011 \\
0.92\end{array}$ & $\begin{array}{l}-0.0009 \\
-0.999\end{array}$ & $\begin{array}{c}-0.0007 \\
-0.83\end{array}$ \\
\hline $\begin{array}{l}\text { Contractual Savings Development } \\
\text { ( Financial assets, } \% \text { GDP) }\end{array}$ & $\begin{array}{c}-0.0036 * * * \\
-4.00\end{array}$ & $\begin{array}{c}-0.003 \\
-3.35\end{array}$ & $\begin{array}{c}-0.017 * * \\
-4.60\end{array}$ & $\begin{array}{c}-0.021 \text { * } \\
-6.35\end{array}$ \\
\hline Year Dummies & Yes & Yes & Yes & Yes \\
\hline Wald Test & $676.5(20)$ & $1190.2(20)$ & $2088(48)$ & 2411 (48) \\
\hline Nb of Observations & 153 & 153 & 153 & 151 \\
\hline $\begin{array}{l}\mathrm{Nb} \text { of Years Included } \\
\mathrm{Nb} \text { of Countries }\end{array}$ & $\begin{array}{c}7 \\
30\end{array}$ & $\begin{array}{c}7 \\
30\end{array}$ & $\begin{array}{c}7 \\
30\end{array}$ & $\begin{array}{c}7 \\
30\end{array}$ \\
\hline
\end{tabular}

Method of estimation:

GLS, with heteroscedastic arror structure and no autocorrelation within panel; no cross-sectional correlation.

Instruments dated $t-1$ for contractual savings variable:

contractual savings variable, real GDP per capita growh, rate of change of M2/GDP, rate of change of real effective exchange rate,

volatility of inflation, volatility of interest rate, openness, share of the population over 64 , bank credit, market capitalization and liquidity 
Gregorio Impavido, Alberto R. Musalem, and Thierry Tressel

\section{Table 10 : Contractual Savings Institutions and Bank Liabilities \\ Pooled and Panel Estimates}

\begin{tabular}{|c|c|c|c|c|}
\hline \multirow{2}{*}{$\begin{array}{l}\text { Dependent Variable: } \\
\begin{array}{l}\text { Explanatory Variables : } \\
\text { CS variable }\end{array}\end{array}$} & \multicolumn{4}{|c|}{ Customer and Short-term Funding / Total Asset } \\
\hline & dated $t-1^{0}$ & $N$ & Fixed Effects & iffects \\
\hline \multicolumn{5}{|l|}{ Banks' Characteristics : } \\
\hline Capitalization (ETA) & $\begin{array}{l}-0.134 \\
-0.34 \\
-0.18 * * *\end{array}$ & $\begin{array}{c}-0.331 \\
-0.82 \\
-0.19 * * *\end{array}$ & $\begin{array}{l}-0.32 \\
-0.89 \\
01\end{array}$ & $\begin{array}{l}-0.48 \\
-1.32 \\
0.11\end{array}$ \\
\hline Non Earnings Assets (CTA) & $\begin{array}{l}-0.10 \\
-2.72 \\
-0.89\end{array}$ & $\begin{array}{c}-0.19 \\
-1.11 \\
-1.11\end{array}$ & $-0.24^{\star \star \star}$ & $\begin{array}{l}0.11 \\
1.61 \\
0.3\end{array}$ \\
\hline Overhead (OTTA) & $\begin{array}{l}-3.93 \\
1.469 \\
1.51\end{array}$ & $\begin{array}{l}-8.10 \\
1.591 \\
1.61\end{array}$ & $\begin{array}{l}-3.5 \\
5.06^{\star \star *} \\
5.67\end{array}$ & $\begin{array}{l}1.4 \\
4.71^{\star * * *} \\
5.39\end{array}$ \\
\hline \multicolumn{5}{|l|}{ Macroeconomic Factors : } \\
\hline Inflation & $\begin{array}{l}-0.07 \\
-0.80\end{array}$ & $\begin{array}{l}-0.05 \\
-0.52\end{array}$ & $\begin{array}{l}0.41^{\star * *} \\
2.52\end{array}$ & $\begin{array}{l}0.19 \\
1.07\end{array}$ \\
\hline GDP growth & $\begin{array}{l}0.02 \\
0.07\end{array}$ & 0.10 & $\begin{array}{l}0.53^{\star * *} \\
3.89\end{array}$ & $0.33^{\star \star}$ \\
\hline Log (GDP/Capita) & $-5.44^{* \star *}$ & $-6.05^{0.40}$ & $-13.61^{3.89 *}$ & $-14.61^{\star \star \star}$ \\
\hline Government Budget Balance (\% GDP) & $\begin{array}{l}-3.41 \\
0.62 * \hbar \star \\
3.51\end{array}$ & $\begin{array}{l}-3.65 \\
0.66^{\star * \star} \\
3.67\end{array}$ & $\begin{array}{c}-3.37 \\
0.36 \\
2.19\end{array}$ & $\begin{array}{l}-3.85 \\
0.22 \\
1.18\end{array}$ \\
\hline Financial System Development : & & & & \\
\hline Credit to Private Sector & 0.01 & 0.01 & $-0.11 * * \star$ & $-0.19^{* * *}$ \\
\hline Stock Market Capitalization & $\begin{array}{l}0.33 \\
0.04\end{array}$ & $\begin{array}{l}0.45 \\
0.03\end{array}$ & $\begin{array}{l}-3.43 \\
0.01\end{array}$ & $\begin{array}{l}-3.76 \\
0.03\end{array}$ \\
\hline Stock Market Activity & $\begin{array}{c}1.34 \\
-0.05\end{array}$ & $\begin{array}{c}0.98 \\
-0.04\end{array}$ & $\begin{array}{l}0.77 \\
-0.01\end{array}$ & $\begin{array}{c}1.38 \\
-0.02\end{array}$ \\
\hline $\begin{array}{l}\text { Stock Market Liquidity } \\
\text { (Turnover Ratio) }\end{array}$ & $\begin{array}{l}-1.34 \\
-0.021 \\
-1.01\end{array}$ & $\begin{array}{l}-1.00 \\
-0.034 \\
-1.52\end{array}$ & $\begin{array}{l}-0.61 \\
-0.004 \\
-0.25\end{array}$ & $\begin{array}{c}-0.95 \\
0.001 \\
0.07\end{array}$ \\
\hline $\begin{array}{l}\text { Contractual Savings Development } \\
\text { ( Financial assets, \% GDP) }\end{array}$ & $\begin{array}{c}0.01 \\
0.44\end{array}$ & $\begin{array}{c}0.01 \\
0.37\end{array}$ & $\begin{array}{c}-0.14^{* * *} \\
-2.95\end{array}$ & $\begin{array}{c}-0.11 * * \\
-2.26\end{array}$ \\
\hline Year Dummies & Yes & Yes & Yes & Yes \\
\hline Wald Test & $123.14(19)$ & $163.1(19)$ & $4153(47)$ & $4632(47)$ \\
\hline Nb of Observations & 156 & 153 & 156 & 153 \\
\hline $\mathrm{Nb}$ of Years Included & 7 & 7 & 7 & 7 \\
\hline $\mathrm{Nb}$ of Countries & 30 & 30 & 30 & 30 \\
\hline
\end{tabular}

Method of estimation:

GLS, with heteroscedastic error structure and no autocorrelation within panel; no cross-sectional correlation.

Instruments dated $\mathrm{t}-1$ for contractual savings variable:

contractual savings variable, real GDP per capita growth, rate of change of M2/GDP, rate of change of real effective exchange rate,

volatility of inflation, volatility of interest rate, openness, share of the population over 64 , bank credit, market capitalization and liquidity 


\section{Policy Research Working Paper Series}

Title

WPS2730 Antidumping as Safeguard Policy
$\begin{array}{r}\text { WPS2731 An Alternative Technical Education } \\ \text { System in Mexico: A Reassessment } \\ \text { of CONALEP }\end{array}$
WPS2732 The Unbalanced Uruguay Round
Outcome: The New Areas in Future
WTO Negotiations

WPS2734 Agricultural Markets in Benin and Malawi: The Operation and Performance of Traders

WPS2735 Shifting Tax Burdens through Exemptions and Evasion: An Empirical Ritva Reinikka Investigation of Uganda

WPS2736 Social Policy and Macroeconomics: The Irish Experience

WPS2737 Mode of Foreign Entry, Technology Transfer, and Foreign Direct Investment Policy

WPS2738 Assisting the Transition from Workfare to Work: A Randomized Experiment

WPS2739 Poverty, Education, and Health in Indonesia: Who Benefits from Public Spending?

WPS2740 Are Men Benefiting from the New Economy? Male Economic Marginalization in Argentina, Brazil, and Costa Rica
Author

Date

Contact for paper

J. Michael Finger
Francis $\mathrm{Ng}$
Sonam Wangchuk

December 2001

R. Simms

37156

Gladys Lopez-Acevedo

December 2001

M. Geller 85155

J. Michael Finger Julio J. Nogues

December 2001

R. Simms 37156

Bernard Hoekman

December 2001

R. Martin

Constantine Michalopoulos

Maurice Schiff

David Tarr

Marcel Fafchamps

December 2001

P. Kokila

Eleni Gabre-Madhin 33716

December 2001

H. Sladovich 37698

December 2001

J. Turner 81767

December 2001

R. Martin 39065

Marcelo Olarreaga

Kamal Saggi

Emanuela Galasso

Martin Ravallion

December 2001

C. Gunanan

Agustin Salvia

Peter Lanjouw

Menno Pradhan

December 2001

P. Sader

33902

Fadia Saadah

Haneen Sayed

Robert Sparrow

Omar Arias

December 2001

S. Nyairo 34635 


\section{Policy Research Working Paper Series}

Title

WPS2741 Female Wage Inequality in Latin American Labor Markets

WPS2742 Sectoral Allocation by Gender of Latin American Workers over the Liberalization Period of the 1960s

WPS2743 Breadwinner or Caregiver? How Household Role Affects Labor Choices in Mexico

WPS2744 Gender and the Allocation of Adult Time: Evidence from the Peru LSMS Panel Data

WPS2745 Children's Work and Schooling: Does Gender Matter? Evidence from the Peru LSMS Panel Data

WPS2746 Complementarity between Multilateral Dilip Ratha Lending and Private Flows to Developing Countries: Some Empirical Results

WPS2747 Are Public Sector Workers Underpaid? Sarah Bales Appropriate Comparators in a Martín Rama Developing Country

WPS2748 Deposit Dollarization and the Financial Patrick Honohan Sector in Emerging Economies Anqing Shi

WPS2749 Loan Loss Provisioning and Economic Luc Laeven Slowdowns: Too Much, Too Late? Giovanni Majnoni

WPS2750 The Political Economy of Commodity Masanori Kondo Export Policy: A Case Study of India
Date

December 2001

December 2001

December 2001

December 2001

December 2001

December 2001

December 2001

December 2001

December 2001

December 200
S. Nyairo

34635

S. Nyairo 34635

Contact

for paper

S. Nyairo 34635

S. Nyairo 34635

S. Nyairo 34635

S. Crow 30763

H. Sladovich 37698

A. Yaptenco 38526

R. Vo 33722

D. Umali-Deininger 30419 